University of Nebraska - Lincoln

DigitalCommons@University of Nebraska - Lincoln

Publications from USDA-ARS / UNL Faculty

U.S. Department of Agriculture: Agricultural

Research Service, Lincoln, Nebraska

2017

Payette Russet: a Dual-Purpose Potato Cultivar with ColdSweetening Resistance, Low Acrylamide Formation, and Resistance to Late Blight and Potato Virus $Y$

R. G. Novy

USDA-ARS, Rich.Novy@ars.usda.gov

J. L. Whitworth

USDA-ARS, jonathan.whitworth@ars.usda.gov

J. C. Stark

University of Idaho

B. L. Schneider

USDA-ARS, Brian.Schneider@ars.usda.gov

N. R. Knowles

Washington State University, rknowles@wsu.edu

See next page for additional authors

Follow this and additional works at: https://digitalcommons.unl.edu/usdaarsfacpub

Novy, R. G.; Whitworth, J. L.; Stark, J. C.; Schneider, B. L.; Knowles, N. R.; Pavek, M. J.; Knowles, L. O.; Charlton, B. A.; Sathuvalli, V.; Yilma, S.; Brown, C. R.; Thornton, M.; Brandt, T. L.; and Olsen, N., "Payette Russet: a Dual-Purpose Potato Cultivar with Cold-Sweetening Resistance, Low Acrylamide Formation, and Resistance to Late Blight and Potato Virus Y" (2017). Publications from USDA-ARS / UNL Faculty. 1795. https://digitalcommons.unl.edu/usdaarsfacpub/1795

This Article is brought to you for free and open access by the U.S. Department of Agriculture: Agricultural Research Service, Lincoln, Nebraska at DigitalCommons@University of Nebraska - Lincoln. It has been accepted for inclusion in Publications from USDA-ARS / UNL Faculty by an authorized administrator of DigitalCommons@University of Nebraska - Lincoln. 


\section{Authors}

R. G. Novy, J. L. Whitworth, J. C. Stark, B. L. Schneider, N. R. Knowles, M. J. Pavek, L. O. Knowles, B. A. Charlton, V. Sathuvalli, S. Yilma, C. R. Brown, M. Thornton, T. L. Brandt, and N. Olsen 


\title{
Payette Russet: a Dual-Purpose Potato Cultivar with Cold-Sweetening Resistance, Low Acrylamide Formation, and Resistance to Late Blight and Potato Virus Y
}

\author{
R. G. Novy ${ }^{1}$ • J. L. Whitworth ${ }^{1}$ • J. C. Stark ${ }^{2}$ • B. L. Schneider ${ }^{1}$ • N. R. Knowles ${ }^{3}$ • \\ M. J. Pavek ${ }^{3}$ - L. O. Knowles ${ }^{3}$ - B. A. Charlton ${ }^{4}$ - V. Sathuvalli ${ }^{5}$ S. Yilma ${ }^{6}$. \\ C. R. Brown ${ }^{7} \cdot$ M. Thornton ${ }^{8} \cdot$ T. L. Brandt ${ }^{9} \cdot$ N. Olsen ${ }^{9}$
}

Published online: 3 December 2016

(C) The Potato Association of America 2016

This document is a U.S. government work and
is not subject to copyright in the United States.

\begin{abstract}
Payette Russet is a full season, russet-skinned potato cultivar notable for its cold-sweetening resistance and associated low acrylamide formation, making it ideally suited for processing into French fries and other potato products. Low asparagine and reducing sugar concentrations in Payette Russet tubers contribute to an $81 \%$ reduction in acrylamide content in French fries relative to cultivars Ranger Russet and Russet Burbank following eight months storage at $9{ }^{\circ} \mathrm{C}$. In three years of evaluations in the Western Regional Potato Variety Trials, average yield of Payette Russet was intermediate between Ranger Russet and Russet Burbank, but Payette Russet had the highest U.S. No. 1 yield when averaged across all eight trial locations. Acceptably low tuber glucose concentrations
\end{abstract}

R. G. Novy

Rich.Novy@ars.usda.gov

1 U. S. Department of Agriculture (USDA)-Agricultural Research Service (ARS), Aberdeen Research \& Extension Center, Aberdeen, ID 83210, USA

2 Idaho Falls R \& E Center, University of Idaho, Idaho Falls, ID 83402 , USA

3 Washington State University, Pullman, WA 99164, USA

4 Klamath Basin R \& E Center, Oregon State University, Klamath Falls, OR 97603, USA

5 Hermiston Agricultural R\&E Center, Oregon State University, Hermiston, OR 97838, USA

6 Oregon State University, Corvallis, OR 97331, USA

7 USDA-ARS, Prosser, WA 99350, USA

8 Southwest Idaho R\&E Center, University of Idaho, Parma, ID 83660 , USA

9 Kimberly R\&E Center, University of Idaho, Kimberly, ID 83341, USA
$(<0.10 \%$ glucose FWB) were maintained in Payette Russet following up to nine months storage at temperatures as low as $5.6^{\circ} \mathrm{C}$ with consistently acceptable French fry color scores obtained (USDA value $\leq 2.0$ ). Reducing sugars are also maintained uniformly throughout Payette Russet tubers, resulting in a low incidence of sugar ends and reduced mottling in French fries relative to standard processing cultivars. Long tuber dormancy also benefits long-term storage for processing. With its russet skin, Payette Russet could also be used for fresh-pack, and its assemblage of disease resistances makes it especially suitable for organic production, or for use by growers and companies seeking greater sustainability in their production. Payette Russet is resistant to foliar and tuber late blight, common scab, and has extreme resistance to PVY conferred by the presence of the Rysto resistance gene. Payette Russet also has a moderate level of resistance to Verticillium wilt, early blight, and corky ringspot. It is susceptible to Fusarium dry rot (F. sambucinum), therefore production and storage management guidelines are provided to minimize tuber infection. Payette Russet displays a low incidence of second growth and growth cracks, especially relative to Russet Burbank, and is intermediate between Ranger Russet and Russet Burbank for incidence of hollow heart/brown center. Blackspot bruise expression for Payette Russet is similar to Russet Burbank and reduced relative to Ranger Russet. Payette Russet was more susceptible to shatter bruise, internal brown spot, and tuber weight loss in storage relative to the industry standard cultivars. Payette Russet was released in 2015 by the USDA-ARS and the Agricultural Experiment Stations of Idaho, Oregon, and Washington, and is a product of the Northwest (Tri-State) Potato Variety Development Program.

Resumen Payette Russet es una variedad de papa de ciclo completo y piel corrugada notable por su resistencia al 
endulzamiento por frío y por su asociación con baja formación de acrilamida, haciéndola idealmente ajustada para procesamiento en papas a la francesa y otros productos de papa. Las bajas concentraciones de asparagina y de azucares reductores en los tubérculos de Payette Russet contribuyen a una reducción del $81 \%$ en el contenido de acrilamida en las papas a la francesa en relación con las variedades Ranger Russet y Russet Burbank después de ocho meses de almacenamiento a $9{ }^{\circ} \mathrm{C}$. En tres años de evaluaciones en los ensayos de variedades de papa regionales del oeste, el promedio de rendimiento de Payette Russet fue intermedio entre Ranger Russet y Russet Burbank, pero Payette Russet tuvo el rendimiento más alto de U.S.1 cuando se promedió a lo largo de las ocho localidades de ensayo. Se mantuvieron aceptablemente bajas las concentraciones de glucosa $(<0.10 \%$ de glucosa FWB, peso fresco) en Payette Russet después de nueve meses de almacenamiento a temperaturas tan bajas como $5.6^{\circ} \mathrm{C}$, obteniéndose consistentemente calificaciones de color aceptable en papas a la francesa (valor USDA $\leq 2.0$ ). Los azucares reductores también se mantienen uniformes a lo largo de los tubérculos de Payette Russet, resultando en una baja incidencia de extremos con azúcar y de moteado reducido en las papas a la francesa en relación con las variedades estándar para procesamiento. La dormancia prolongada del tubérculo también beneficia el almacenamiento por largos períodos para proceso. Con su piel corrugada, Payette Russet podría también usarse para empaque en fresco, y su conjunto de resistencias a enfermedades la hace apropiada específicamente para producción orgánica, o para uso por productores y compañías que buscan mayor sustentabilidad en su producción. Payette Russet es resistente al tizón tardío foliar y de tubérculo, a la roña común, y tiene resistencia extrema al PVY conferida por la presencia del gene Rysto de resistencia. Payette Russet también tiene un nivel moderado de resistencia a la marchitez por Verticillium, al tizón temprano, y a la mancha anular corchosa. Es susceptible a la pudrición seca por Fusarium (F. sambucinum), de aquí que se suministran las guías de manejo de la producción y el almacén, para minimizar la infección de tubérculo. Payette Russet exhibe baja incidencia de crecimiento secundario y de cuarteaduras por crecimiento, especialmente en relación con Russet Burbank, y es intermedia entre Ranger Russet y Russet Burbank en la incidencia de corazón hueco/centro café. La expresión de mancha negra por daño mecánico en Payette Russet es similar a la de Russet Burbank y reducida en relación a Ranger Russet. Payette Russet fue más susceptible a rompimiento por magulladuras, mancha café interna y pérdida de peso de tubérculo en almacén en relación a las variedades estándar de la industria. Payette Russet se liberó en el 2015 por el USDA ARS y las Estaciones Agrícolas Experimentales de Idaho, Oregon y Washington, y es un producto del Programa de Desarrollo de Variedades de Papa Noroccidental (Tri-State).
Keywords Solanum tuberosum · Breeding · Variety · Processing

\section{Introduction}

Payette Russet is a product of the cooperative USDA/ Agricultural Research Service (ARS) and University of Idaho potato breeding and varietal development program in Aberdeen, ID. Payette Russet originated from a hybridization made in 2002 by ARS personnel at Aberdeen between breeding clone EGAO9702-2 and GemStar Russet (Love et al. 2006) (Fig. 1). The hybridization was made to generate progeny having the late blight resistance of EGAO9702-2 and the attractive tuber type and processing quality of GemStar Russet. Both parents also were identified as having exceptional cold-sweetening resistance, with pyramiding of genes associated with this trait also being an objective of the hybridization. Parental clone EGAO9702-2 was a selection originating from true potato seed provided by Dr. Ewa ZimnochGuzowska, Młochów Research Center, Plant Breeding and Acclimatization Institute (IHAR), Młochów, Poland to Dr. Chuck Brown, USDA-ARS, Prosser, WA. Seedling tubers from the Polish seed were generated at Aberdeen, ID in 1997, with field selection of EGAO9702-2 occurring in Corvallis, OR in 1998. Other potato cultivars also represented in the pedigree of Payette Russet include Gem Russet (Love et al. 2002), Russet Norkotah (Johansen et al. 1988), Atlantic (Webb et al. 1978), Lemhi Russet ( Pavek et al. 1981), and the Polish cultivar, Certa (European Cultivated Potato Database).

True potato seed from the hybridization of EGAO9702-2 and GemStar Russet were planted and germinated in the greenhouse in 2003 for the production of seedling tubers, with Payette Russet selected in the field in 2004 from a single hill trial at Aberdeen, ID. Payette Russet was then grown in a 12hill plot at Aberdeen Idaho in 2005, and from 2006 through 2010 in replicated yield trials at Aberdeen and Kimberly, Idaho. It was entered in the Tri-State Variety Trials in Idaho, Oregon, and Washington in 2011, and subsequently advanced to the Western Regional Potato Variety Trials where it was evaluated in California, Colorado, Idaho, Oregon, and Washington in 2012 through 2014. It was also evaluated in the National Fry Processing Trial from 2011 to 2015 where it was first identified as having low acrylamide content in its fries relative to industry standards, Russet Burbank and Ranger Russet.

The decision to release A02507-2LB as Payette Russet was based on good agronomic performance in trials over years and locations, cold-sweetening resistance with associated low acrylamide forming potential, late blight resistance in both the tuber and foliage, common scab resistance, extreme resistance (all strains of PVY), as well as moderate resistance to Verticillium wilt, early blight, and corky ringspot. The name, 
Fig. 1 Pedigree of Payette Russet

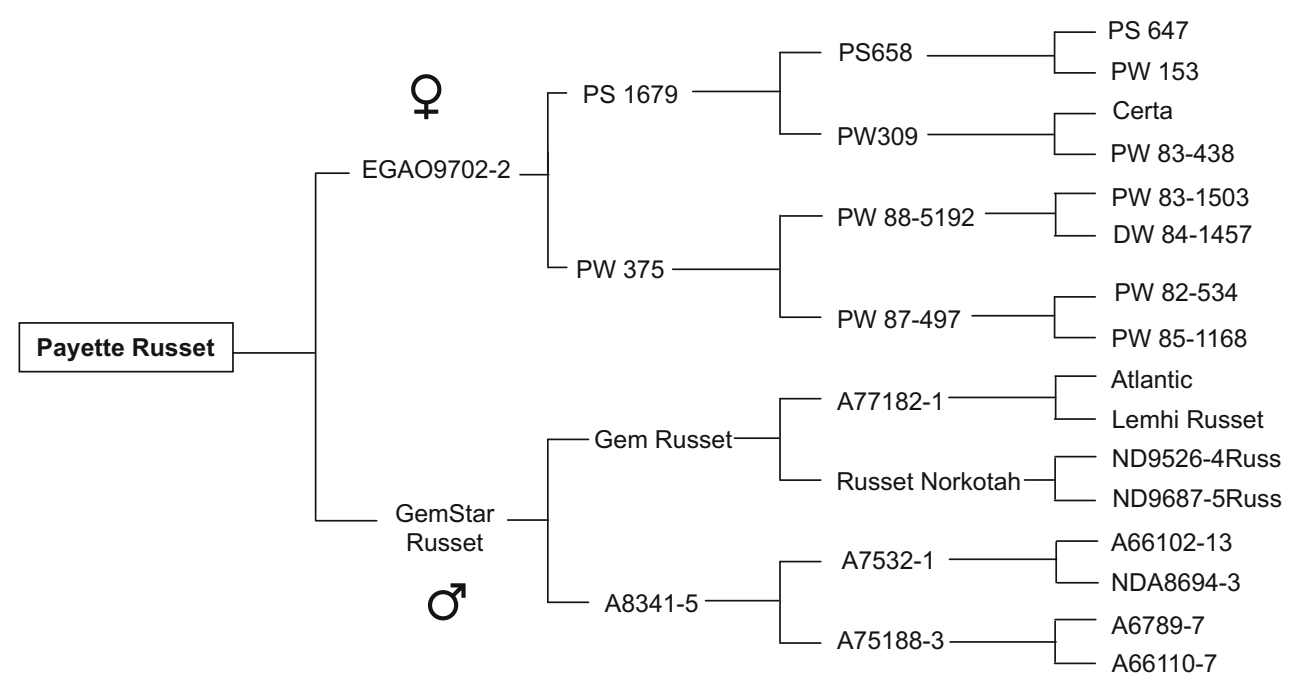

Payette Russet, was chosen to recognize the scenic beauty of Payette Lake and River in Idaho. Release documents for Payette Russet were completed in 2015, with the release made jointly by the USDA-ARS and the experiment stations of Idaho, Washington, and Oregon, which represent the collaborating institutions that comprise the Northwest (Tri-State) Potato Variety Development Program.

\section{Varietal Description}

Plant and tuber descriptions of Payette Russet were obtained from field evaluations conducted from 2012 to 2014 at Aberdeen, ID.

\section{Plants (Figs. 2a-c)}

Growth Habit: Erect to semi-erect vine expressing late vine maturity with senescence commencing 130 days after planting. Vine architecture is closed with stems barely visible due to coverage by foliage. Stems: Anthocyanin pigmentation is absent with moderately prominent wings. Leaves: mediumgreen that most closely align in color with value $137 \mathrm{~B}$ of the Royal Horticultural Society Color Chart; closed silhouette, sparse pubescence, and no anthocyanin pigmentation on the petioles. Terminal leaflets: Narrowly ovate shape with an acuminate tip and cordate base and medium margin waviness. Primary leaflets: Range of three to five pairs with an average of 4.1 pairs; medium ovate with a cuspidate tip and obtuse base. Secondary and tertiary leaflets: Three to nine pairs, average of 6.5 pairs. Stipular Leaves: Medium.

\section{Flowers (Fig. 2d)}

The number of inflorescences range from one to seven per plant (average of 4.2), with an average of 9.9 florets per inflorescence. Calyx: Anthocyanin pigmentation is absent. Corolla: White with pentagonal shape. Anthers: Pear-shaped cone. Stigma: Capitate. Pollen: Sterile. Female fertility: Good in crosses with male fertile breeding clones/cultivars. Berry production in the field is absent unless a male- fertile variety is in close proximity to allow for hybrid seed and subsequent berry formation.

\section{Tubers (Fig. 2e)}

Tubers are oblong, medium russeted, with intermediate eye depth and white flesh. Average number of eyes per tuber is 18 compared to Russet Burbank with 27. Tuber set per plant is similar to that of Russet Burbank with generally eight or less tubers. Dormancy: Three years of storage trials with no application of sprout inhibitors were conducted at storage temperatures of $5.6^{\circ}$ to $8.9^{\circ} \mathrm{C}$. Dormancy length of Payette Russet averaged 143 days when held at temperatures ranging from 5.6 to $8.9^{\circ} \mathrm{C}$; which was approximately 24 days shorter than Russet Burbank (167 days) in the same evaluations. Duration of dormancy was defined as the number of days from harvest until $80 \%$ of potatoes had at least one sprout $\geq 5 \mathrm{~mm}$ in length. Russet Burbank is an industry standard for long-term storage due to its extended tuber dormancy. Payette Russet, although slightly shorter in its tuber dormancy than Russet Burbank, nonetheless has potential for its use in long-term storage by the potato industry.

\section{Light Sprouts (Fig. 2f)}

Spherical shape; tip is green with a partially open growth habit and strong expression of pubescence; base of sprout shows blue-violet pigmentation that is strongly expressed with a moderate number of root initials. 
Fig. 2 Payette Russet: a field plant comparison relative to Russet Burbank, b whole plant, c leaf, $\mathbf{d}$ flower, ex, external and internal tuber appearance, and $\mathbf{f}$ light sprouts on tuber

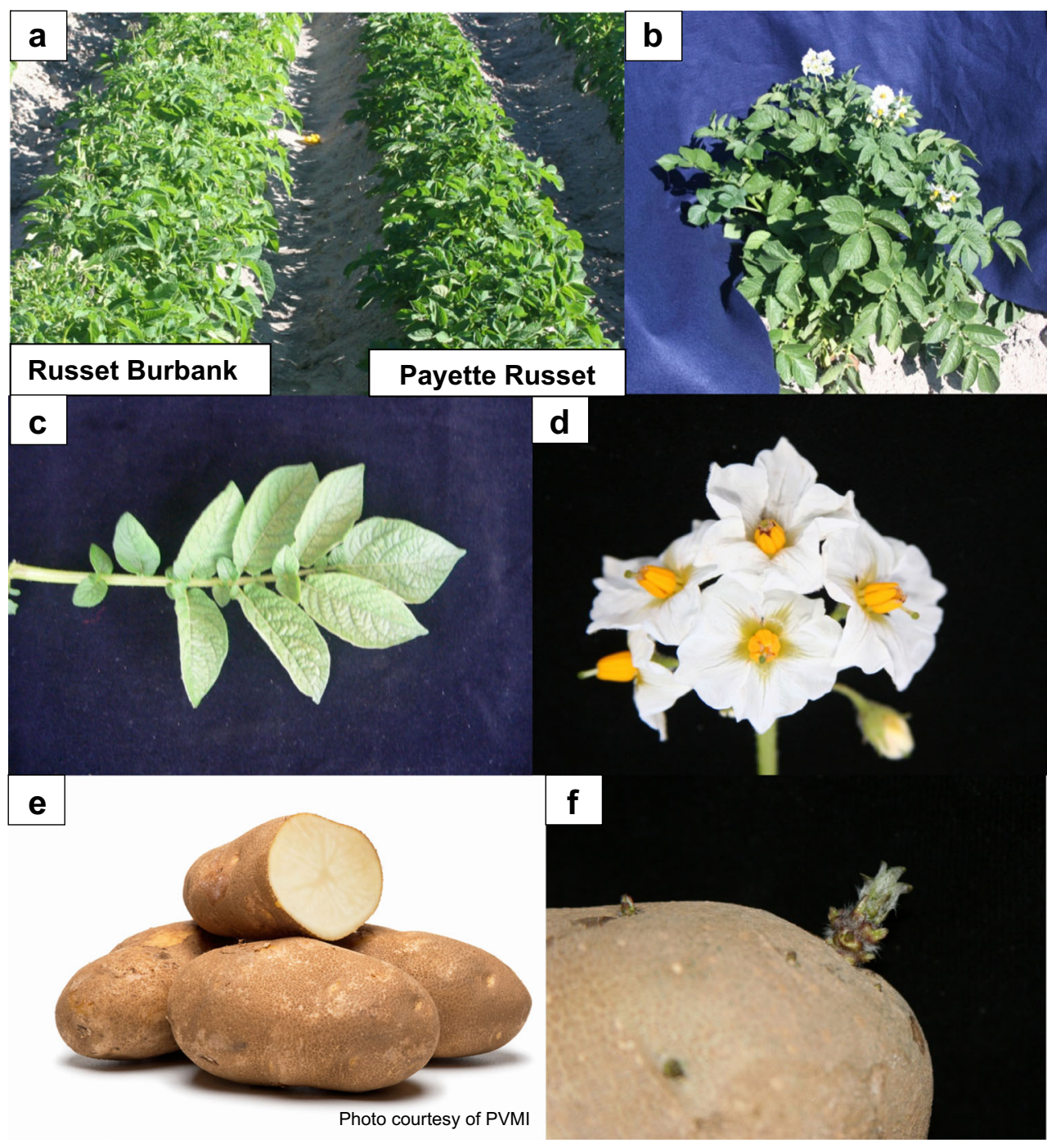

\section{Agronomic Performance}

Total yield of Payette Russet did not significantly differ from Russet Burbank or Ranger Russet in seven full-season trials conducted at Aberdeen and Kimberly, ID (Table 1); sites which are located within commercial potato production regions of southern Idaho. However, U.S. No. 1 yield of Payette Russet was 11.7 t/ha higher than Russet Burbank due to a much higher percentage of U.S. No. 1 tubers (United States Standards for Grades of Potatoes, 2011). Although the percentage of U.S. No. 1 yield was also significantly higher for Payette Russet relative to Ranger Russet, the U.S. No. 1 yield between the two cultivars did not differ statistically (Table 1). Payette Russet had significantly higher specific gravity than both Ranger Russet and Russet Burbank in the Idaho trials. It also had a significantly higher percentage of tubers in the oversize ( $>340 \mathrm{~g}$ ) category relative to the check cultivars, with $5 \%$ less tubers in the $170-340 \mathrm{~g}$ range relative to Ranger Russet and $11 \%$ higher in the same tuber category relative to Russet Burbank. The 114-169 g and $<114$ g tuber categories were virtually identical among all three cultivars. Tuber defects (cull category) were significantly lower for Payette Russet (6\%) than for Ranger Russet (13\%) and Russet Burbank (27\%). Merit ratings for Payette Russet were significantly higher relative to Russet Burbank and similar to those of Ranger Russet (Table 1).

Payette Russet also was evaluated over a four year period in trials conducted in Idaho, Oregon, and Washington (Table 2). Total yields of Payette Russet were higher than Ranger Russet and Russet Burbank when averaged across all three states with much higher yields of Payette Russet relative to check cultivars noted at the Hermiston, OR trial site. U.S. No. 1 yield of Payette Russet consistently exceeded that of Ranger Russet and Russet Burbank at all locations, averaging 7.6 and $19.8 \mathrm{t} / \mathrm{ha}$ higher yields respectively across all sites. The percent U.S. No. 1 yield was highest for Payette Russet at all locations. Specific gravities of Payette Russet were also consistently greater than those of Ranger Russet 
Table 1 Average total yield, U.S. No. 1 yield, percent U.S. No. 1 tubers, specific gravity, tuber merit ratings and size distribution, French fry color, and percentage of sugar ends of Payette Russet, Ranger Russet, and Russet Burbank from seven full-season yield trials (125-135 days) conducted at Aberdeen and Kimberly, ID from 2006 to 2010

\begin{tabular}{|c|c|c|c|c|c|c|c|c|c|c|c|c|c|}
\hline \multirow[b]{2}{*}{ Cultivar } & \multicolumn{2}{|c|}{ Yield (t/ha) } & \multirow[t]{2}{*}{$\%$ No. 1} & \multirow[t]{2}{*}{ Specific Gravity $^{\mathrm{a}}$} & \multicolumn{5}{|c|}{ Tuber size distribution as percent of total yield } & \multirow[t]{2}{*}{ Merit $^{\mathrm{b}}$} & \multicolumn{2}{|c|}{ Fry color ${ }^{\mathrm{c}}$} & \multirow{2}{*}{$\begin{array}{l}\text { Fry sugar } \\
\text { ends }{ }^{\mathrm{d}} \\
7.2^{\circ}\end{array}$} \\
\hline & Total & U.S. No. 1 & & & $>340 \mathrm{~g}$ & $170-340 \mathrm{~g}$ & $114-169 \mathrm{~g}$ & $<114 \mathrm{~g}$ & Cull & & $4.4^{\circ}$ & $7.2^{\circ}$ & \\
\hline Payette Russet & $51.1 \mathrm{a}^{\mathrm{e}}$ & $43.3 \mathrm{a}$ & $85 \mathrm{a}$ & $1.090 \mathrm{a}$ & $27 \mathrm{a}$ & $44 b$ & $13 \mathrm{a}$ & $9 \mathrm{a}$ & $6 c$ & $3.3 \mathrm{a}$ & $1.8 \mathrm{~b}$ & $0.3 b$ & $5.2 b$ \\
\hline Ranger Russet & $50.5 \mathrm{a}$ & $39.3 \mathrm{a}$ & $77 \mathrm{~b}$ & $1.084 \mathrm{~b}$ & $16 b$ & $49 \mathrm{a}$ & $13 \mathrm{a}$ & $9 \mathrm{a}$ & $13 b$ & $2.9 \mathrm{ab}$ & $3.2 \mathrm{a}$ & $0.8 \mathrm{a}$ & $32.7 \mathrm{a}$ \\
\hline Russet Burbank & $48.9 \mathrm{a}$ & $31.6 b$ & $64 c$ & $1.079 \mathrm{c}$ & $18 \mathrm{~b}$ & $33 c$ & $12 \mathrm{a}$ & $9 a$ & $27 \mathrm{a}$ & $2.5 \mathrm{~b}$ & $3.6 \mathrm{a}$ & $0.8 \mathrm{a}$ & $26.7 \mathrm{a}$ \\
\hline
\end{tabular}

${ }^{1}$ Specific gravities were determined using the weight-in-air, weight-in-water method within one month of harvest

${ }^{\mathrm{b}}$ Merit ratings of tubers: 1 = Very Poor, 2 = Poor, 3 = Average, 4 = Good, $5=$ Excellent

${ }^{\mathrm{c}}$ French fry scores rated using USDA standards, with $0=$ light and $4=$ dark. A rating $\leq 2.0$ is an acceptable score. Tubers were evaluated following three to six months storage at 4.4 or $7.2^{\circ} \mathrm{C}$

${ }^{\mathrm{d}}$ Percentage of fries with sugar ends following storage at $7.2^{\circ} \mathrm{C}$

${ }^{\mathrm{e}}$ Mean values followed by the same letter are not significantly different from one another $(P<0.05)$ based on Tukey's test

and Russet Burbank at all trial sites. Fresh and processing merit scores were consistently highest for Payette across all three states (Table 2).

In three years of evaluations in the Western Regional Potato Variety Trials (Table 3), Payette Russet total yields were intermediate between Ranger Russet and Russet Burbank, but it had the highest U.S. No. 1 yield and percentage of U.S. No. 1 tubers among the three cultivars, when averaged across all eight trial locations. When one looks specifically at trial sites, Payette Russet had the highest U.S. No. 1 yield at six of the eight locations and the highest percentage of U.S. No. 1 yield at seven of the eight (Table 3). The specific gravities of Payette Russet exceeded Russet Burbank at all eight trial sites with the average value across all sites exceeding Ranger Russet by 0.004 . Fresh and processing merit scores averaged across all eight trial sites were highest for Payette Russet.

\section{Tuber Quality Characteristics and Usage}

\section{Tuber Sugars, Fry Color, and Dormancy}

In two of the three years of evaluations at Kimberly, ID, percent sucrose in Payette Russet was similar to that of Russet Burbank (3 yr. mean) throughout storage at 5.6, 7.2, and $8.9^{\circ} \mathrm{C}$ (Fig. 3a.). In one of the three years tested (2014-15), sucrose was significantly lower in storage in Payette Russet compared to the mean of Russet Burbank.

Payette Russet is notable for the production of tubers that retain very low reducing sugar concentrations in storage (Figs. 3b, 4a, and Table 4). Reducing sugar concentrations in Russet Burbank and Ranger Russet tubers were 5.7- and 3.6fold higher, respectively, than in Payette Russet tubers following 60 days storage at $8.9^{\circ} \mathrm{C}$ (Fig. 4a). Sugars increased linearly $(P<0.001)$ with decreasing storage temperature in all cultivars; however, the rates and absolute increases from 8.9 to $4{ }^{\circ} \mathrm{C}$ were substantially greater for Russet Burbank and Ranger Russet tubers (Fig. 4a), characterizing the low temperature sweetening resistance of Payette Russet. Even when stored for up to nine months at $5.6{ }^{\circ} \mathrm{C}$, Payette Russet glucose concentrations consistently remained below $0.10 \%$ (fresh weight basis), and were acceptable for processing, indicative of its resistance to cold-induced sweetening (Fig. 3b). Average Russet Burbank glucose concentrations under the same storage parameters exceeded the acceptable level of $0.10 \%$ within only 79 days after harvest. At $5.6{ }^{\circ} \mathrm{C}$, the highest percent glucose reached in Payette Russet was $0.065 \%$ at approximately 135 days after harvest in 2014-15. In comparison, the peak mean glucose concentration was $0.23 \%$ in Russet Burbank at 108 days after harvest. At storage temperatures of $7.2{ }^{\circ} \mathrm{C}$ and $8.9{ }^{\circ} \mathrm{C}$, glucose concentrations of Payette Russet remained at or below $0.05 \% \mathrm{FW}$ and $0.03 \% \mathrm{FW}$, respectively (Fig. 3b). These values are all well below the industry maximum threshold of $0.10 \% \mathrm{FW}$ glucose and approximately half the values of those of the mean Russet Burbank values. While heat stress can abolish the inherent low temperature sweetening resistance of many conventionally bred cultivars (Zommick et al. 2014a), Payette Russet displayed robust tolerance to heat stress and retained its low temperature sweetening resistant phenotype (Herman et al. 2016).

The lower accumulation of reducing sugars in Payette Russet tubers is reflected in consistently acceptable fry color scores (USDA $\leq 2.0$ ) with a low incidence of sugar ends following storage of tubers from 4.4 to $7.2{ }^{\circ} \mathrm{C}$ (Fig. 3c, Tables 1, 2, 3, and 4). Over three years of evaluations, fry color of Payette Russet remained acceptable (USDA 2 or lighter) even when stored for up to nine months at $5.6^{\circ} \mathrm{C}$ (Fig.3c). Mottling, a dark, uneven coloration which can occur in fried products was seldom observed in Payette Russet in the three year study with ratings of none to mild when stored at $5.6^{\circ}$ and $7.2 \mathrm{C}$ and none at $8.9^{\circ} \mathrm{C}$. Russet Burbank, in the same study, 
Table 2 Total yield, U.S. No. 1 yield, percent U.S. No. 1 tubers, tuber specific gravity, merit score, fry color, and percentage of sugar ends of Payette Russet, Ranger Russet, and Russet Burbank in full-season irrigated trials grown in Idaho, Oregon, and Washington, 2011 to $2014^{\mathrm{a}}$

\begin{tabular}{|c|c|c|c|c|}
\hline & Idaho & Oregon & Washington & Mean \\
\hline \multicolumn{5}{|l|}{ Total yield $(t / h a)$} \\
\hline Payette Russet & 49.9 & 102.4 & 88.3 & 80.2 \\
\hline Ranger Russet & 51.0 & 90.4 & 88.6 & 76.7 \\
\hline Russet Burbank & 45.2 & 97.1 & 83.6 & 75.3 \\
\hline \multicolumn{5}{|c|}{ U.S. No. 1 yield (t/ha) } \\
\hline Payette Russet & 39.1 & 87.2 & 77.6 & 68.0 \\
\hline Ranger Russet & 38.2 & 71.5 & 71.4 & 60.4 \\
\hline Russet Burbank & 24.1 & 67.2 & 53.2 & 48.2 \\
\hline \multicolumn{5}{|l|}{ \% U.S. No. 1} \\
\hline Payette Russet & 79 & 85 & 88 & 84 \\
\hline Ranger Russet & 75 & 80 & 81 & 79 \\
\hline Russet Burbank & 54 & 70 & 73 & 66 \\
\hline \multicolumn{5}{|l|}{ Specific gravity ${ }^{b}$} \\
\hline Payette Russet & 1.087 & 1.086 & 1.091 & 1.088 \\
\hline Ranger Russet & 1.088 & 1.076 & 1.082 & 1.082 \\
\hline Russet Burbank & 1.076 & 1.073 & 1.077 & 1.075 \\
\hline \multicolumn{5}{|c|}{ Merit Score ${ }^{c}$ (Fresh/Processing) } \\
\hline Payette Russet & $3.0 / 4.4$ & $2.4 / 2.7$ & $2.6 / 4.3$ & $3.0 / 3.3$ \\
\hline Ranger Russet & $1.5 / 3.4$ & $1.3 / 2.3$ & $1.8 / 3.7$ & $2.0 / 2.5$ \\
\hline Russet Burbank & $2.1 / 2.8$ & $1.8 / 2.0$ & $1.0 / 2.0$ & $1.9 / 1.9$ \\
\hline \multicolumn{5}{|c|}{ Fry color from $4.4 C^{d}$} \\
\hline Payette Russet & 1.1 & n.a. & 0.0 & 0.5 \\
\hline Ranger Russet & 2.8 & n.a. & 2.5 & 2.7 \\
\hline Russet Burbank & 3.4 & n.a. & 3.3 & 3.3 \\
\hline \multicolumn{5}{|c|}{ Fry color from $7.2 C^{d}$} \\
\hline Payette Russet & 0.9 & 0.7 & 0.0 & 0.5 \\
\hline Ranger Russet & 1.5 & 1.3 & 1.8 & 1.5 \\
\hline Russet Burbank & 1.9 & 1.8 & 2.8 & 2.1 \\
\hline \multicolumn{5}{|l|}{ \% Sugar ends: $7.2 C$} \\
\hline Payette Russet & 11 & 8 & n.a. & 9 \\
\hline Ranger Russet & 32 & 22 & n.a. & 27 \\
\hline Russet Burbank & 36 & 33 & n.a. & 34 \\
\hline
\end{tabular}

${ }^{\text {a }}$ Trial locations were Aberdeen, ID, Hermiston, OR, and Othello, WA. Means represent combined data from the 2011 Tri-State Potato Variety Trials and the 2012 to 2014 Western Regional Potato Variety Trials

${ }^{\mathrm{b}}$ Specific gravities were determined using the weight-in-air, weight-inwater method

${ }^{\mathrm{c}}$ Merit ratings: 1 = Very Poor, 2 = Poor, 3 = Average, $4=$ Good, $5=$ Excellent

${ }^{\mathrm{d}}$ French fry scores rated using USDA standards, with $0=$ light and $4=$ dark. A rating $\leq 2.0$ is an acceptable score. Storage at given temperatures prior to frying was 42,49 , and 60 days for Oregon, Idaho, and Washington, respectively. These storage durations for ID and OR follow standard protocols used by industry in allowing $2-3$ weeks at 10 to $13{ }^{\circ} \mathrm{C}$ for tuber wound healing and a 2 to 3 degree per week lowering of temperature to the desired holding temperature. For the WA trials, tubers were transferred to 4.4 and $7.2{ }^{\circ} \mathrm{C}$ after a 7-day wound healing period at $10^{\circ} \mathrm{C}$ had mottling symptoms ranging from mild to moderate, with more mottling observed at the lower storage temperature.

Fry color uniformity, measured as the difference in Photovolt light reflectance readings from the stem to bud end of tubers, is important for processing. Payette Russet consistently displayed good fry color uniformity ( $\leq 9.0$ reflectance unit difference) after 7 months of storage, regardless of trial site (Table 4). In contrast, Ranger Russet and Russet Burbank produced non-uniform fry color with processed fries from both significantly exceeding the 9.0 Photovolt reflectance unit difference between bud and stem ends (Table 4). Average Photovolt reflectance readings of Payette Russet fries were also significantly greater (indicative of lighter fry color) than those of standard varieties across all three trial sites (Table 4), providing additional evidence of its cold-sweetening resistance. Fry color uniformity was also evident in the significantly lower incidence of sugar ends in fries of Payette Russet relative to Ranger Russet and Russet Burbank, with Payette Russet consistently having $\leq 9 \%$ sugar ends in fries following storage of tubers at $7.2^{\circ} \mathrm{C}$, while check cultivars displayed $>26 \%$ sugar ends (Tables 1 and 2 ).

Over a five year period, the postharvest process rating of Payette Russet (rating based upon fry color, reducing sugar concentrations, tuber specific gravity, and sensory evaluations following harvest from the field without storage, and following 60 days of storage at 8.9 and $6.7^{\circ} \mathrm{C}$ ) was superior to the ratings for Ranger Russet and Russet Burbank (Table 5). Of a possible 38 points, Payette Russet averaged $91 \%$ of this maximum value, whereas Ranger Russet and Russet Burbank were $72 \%$ and $41 \%$ respectively, demonstrating the enhanced processing merit of Payette Russet relative to the two most widely-grown processing cultivars in North America.

Following 3 months of storage at $8.9^{\circ} \mathrm{C}$, the percentage of sprouted tubers and length of sprouts for Payette Russet was significantly reduced relative to Ranger Russet across all state trial locations (Table 4). Payette Russet displays a tuber dormancy, which although not as long as Russet Burbank in Washington and Oregon based on increased percentage sprouting and sprout length, can nonetheless be categorized as being of long duration. In Idaho, tuber dormancy did not differ from that of Russet Burbank which is recognized as having the longest tuber dormancy among processing varieties. These findings were corroborated by studies conducted at Kimberly, ID over years with tuber dormancy length in Payette Russet being approximately 20 to 25 days shorter than Russet Burbank when held at temperatures ranging from 5.6 to $8.9^{\circ} \mathrm{C}$. While dormancy length is shorter than Russet Burbank, plant emergence from Payette Russet is significantly delayed relative to Russet Burbank. Three years of trials in the Columbia Basin (Othello, WA) showed $50 \%$ emergence at 27 days after planting for Russet Burbank versus 37 DAP for Payette Russet (April 14 planting date, Knowles unpublished data). 
Table 3 Total and U.S. No. 1 yield, percent U.S. No. 1 tubers, specific gravity, and fry color of Payette Russet, Ranger Russet and Russet Burbank in full-season trials in the 2012 to 2014 Western Regional Potato Variety Trials ${ }^{\mathrm{a}}$

\begin{tabular}{|c|c|c|c|c|c|c|c|c|c|}
\hline & \multirow[t]{2}{*}{ CA } & \multirow[t]{2}{*}{$\mathrm{CO}$} & \multicolumn{3}{|l|}{ ID } & \multicolumn{2}{|l|}{ OR } & \multirow[t]{2}{*}{ WA } & \multirow[t]{2}{*}{ Mean } \\
\hline & & & 1 & 2 & 3 & 1 & 2 & & \\
\hline \multicolumn{10}{|l|}{ Total yield $(t / h a)$} \\
\hline Payette Russet & 42.8 & 44.6 & 48.7 & 58.3 & 67.9 & 91.4 & 67.4 & 87.3 & 63.6 \\
\hline Ranger Russet & 50.9 & 45.8 & 49.7 & 65.6 & 78.3 & 81.0 & 60.4 & 87.9 & 65.0 \\
\hline Russet Burbank & 44.2 & 42.3 & 44.2 & 55.5 & 81.6 & 91.4 & 41.0 & 81.3 & 60.2 \\
\hline \multicolumn{10}{|c|}{ U.S. No. 1 yield (t/ha) } \\
\hline Payette Russet & 32.8 & 40.6 & 38.8 & 49.0 & 63.8 & 80.1 & 51.3 & 75.6 & 54.0 \\
\hline Ranger Russet & 39.9 & 39.4 & 36.7 & 44.7 & 69.7 & 65.5 & 30.3 & 69.0 & 49.4 \\
\hline Russet Burbank & 33.0 & 29.5 & 22.9 & 30.9 & 58.0 & 65.6 & 19.0 & 56.7 & 39.4 \\
\hline \multicolumn{10}{|l|}{ \% U.S. No. 1} \\
\hline Payette Russet & 74 & 91 & 80 & 84 & 94 & 87 & 76 & 86 & 84 \\
\hline Ranger Russet & 78 & 86 & 74 & 68 & 89 & 81 & 50 & 79 & 76 \\
\hline Russet Burbank & 74 & 69 & 53 & 56 & 71 & 73 & 46 & 70 & 64 \\
\hline \multicolumn{10}{|l|}{ Specific gravity $^{\mathrm{b}}$} \\
\hline Payette Russet & 1.094 & 1.090 & 1.088 & 1.091 & 1.098 & 1.085 & 1.088 & 1.090 & 1.091 \\
\hline Ranger Russet & 1.096 & 1.091 & 1.089 & 1.085 & 1.085 & 1.075 & 1.094 & 1.082 & 1.087 \\
\hline Russet Burbank & 1.092 & 1.086 & 1.084 & 1.077 & 1.081 & 1.076 & 1.085 & 1.074 & 1.082 \\
\hline \multicolumn{10}{|c|}{ Merit Score $^{\mathrm{c}}$ (Fresh/Processing) } \\
\hline Payette Russet & 2.8/n.a. & $4.7 / 4.7$ & $3.0 / 4.5$ & $3.4 / 4.5$ & $3.0 / 3.8$ & $2.5 / 2.7$ & 3.0/n.a. & $2.4 / 4.3$ & $3.1 / 4.1$ \\
\hline Ranger Russet & 3/1/n.a. & $4.7 / 3.0$ & $2.9 / 3.3$ & $2.5 / 3.3$ & $2.2 / 4.0$ & $2.0 / 2.3$ & 1.5/n.a. & $1.3 / 3.7$ & $2.5 / 3.3$ \\
\hline Russet Burbank & 3.3/n.a. & $3.0 / 3.3$ & $2.1 / 2.7$ & $2.4 / 2.8$ & $1.7 / 3.7$ & $2.0 / 2.0$ & 2.0/n.a. & $0.6 / 1.8$ & $2.1 / 2.7$ \\
\hline \multicolumn{10}{|l|}{ Fry color ${ }^{\mathrm{d}}$} \\
\hline Payette Russet & n.a. & 0.7 & 0.3 & 0.4 & n.a. & 0.7 & n.a. & 0.0 & 0.4 \\
\hline Ranger Russet & n.a. & 2.3 & 0.8 & 0.5 & n.a. & 1.3 & n.a. & 1.7 & 1.3 \\
\hline Russet Burbank & n.a. & 2.3 & 1.2 & 0.8 & n.a. & 1.8 & n.a. & 2.7 & 1.8 \\
\hline
\end{tabular}

${ }^{\mathrm{a}}$ Trial locations were Tulelake (CA), San Luis Valley (CO), Aberdeen (ID-1), Kimberly (ID-2), Parma (ID-3), Hermiston (OR-1), Klamath Falls (OR-2), and Othello (WA); All sites represent three years of data

${ }^{\mathrm{b}}$ Specific gravities were determined using the weight-in-air, weight-in-water method

${ }^{\mathrm{c}}$ Merit ratings: 1 = Very Poor, 2 = Poor, 3 = Average, 4 = Good, 5 = Excellent

${ }^{\mathrm{d}}$ French fry scores rated using USDA standards, with $0=$ light and $4=$ dark. A rating $\leq 2.0$ is an acceptable score. Tubers were evaluated following 6 to 11 weeks storage at $7.2 \mathrm{C}$

The long dormancy of Payette Russet tubers is both a strength and a potential weakness. Depending on storage duration, prolonged dormancy can greatly reduce or even circumvent the need for sprout inhibitors, particularly when tubers can be stored at low temperature (e.g. $4{ }^{\circ} \mathrm{C}$ ) without sweetening. While not yet determined for Payette Russet, long dormancy may also enable delayed application of sprout inhibitor and/or use of lower rates to achieve full season sprout control. On the negative side, prolonged dormancy can lead to slow emergence and plant establishment, particularly in production areas where the crop is planted early (e.g. 170 to 190 days following harvest of the seed). Preliminary work has shown that treatment of Payette Russet seed-tubers with low doses of gibberellin (GA) eliminates the delayed emergence response, resulting in plant establishment equivalent to Ranger Russet (Knowles et al. 2016).

\section{Acrylamide}

The low temperature sweetening resistance of Payette Russet confers low reducing sugar concentrations in its tubers-reducing sugars being a primary contributor to acrylamide formation in products processed at temperatures exceeding $120^{\circ} \mathrm{C}$. The amino acid, asparagine (Asn), also is a precursor in the formation of acrylamide. Payette Russet tubers maintained $26 \%$ less Asn ( $\mathrm{mg} \mathrm{g}^{-1}$ dry weight) than Russet Burbank and $20 \%$ less than Ranger Russet (averaged over storage temperatures) (Fig. 4 b). 
Fig. 3 a and $\mathbf{b}$ Tuber sucrose and glucose concentrations, and $\mathbf{c}$. fry colors (\% reflectance) of Payette Russet over a three-year period (2012-2014) relative to Russet Burbank, following 0 to 270 days of storage at $5.6,7.2$, and $8.9^{\circ} \mathrm{C}$; tubers were from research plots at Kimberly, ID. These three storage temperatures reflect an initial storage of harvested tubers for 14 days at $12.8^{\circ} \mathrm{C}$ followed by an incremental lowering of the temperature by $0.28^{\circ} \mathrm{C}$ per day until the three storage temperatures were reached. Sugar concentrations and fry colors of Russet Burbank represent a three year average. Fry colors with Photovolt light reflectance readings of $\geq 35$ and USDA ratings of $\leq 2.0$ are considered acceptable a

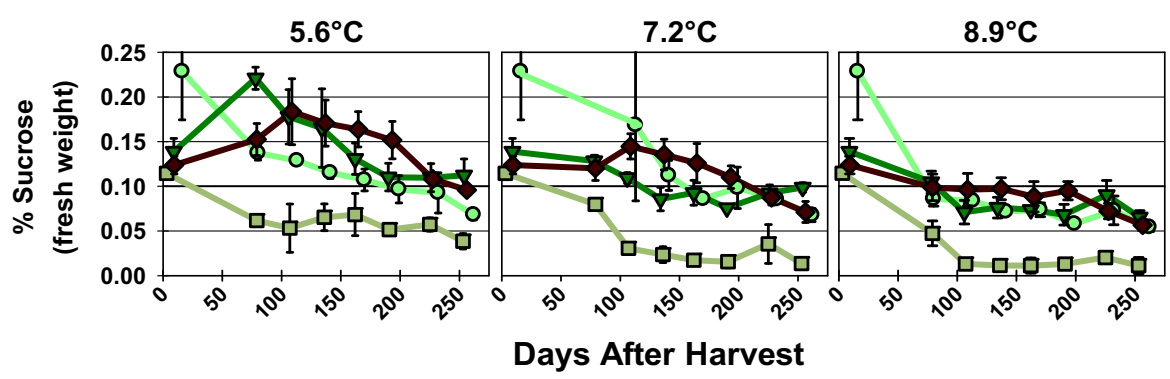

b

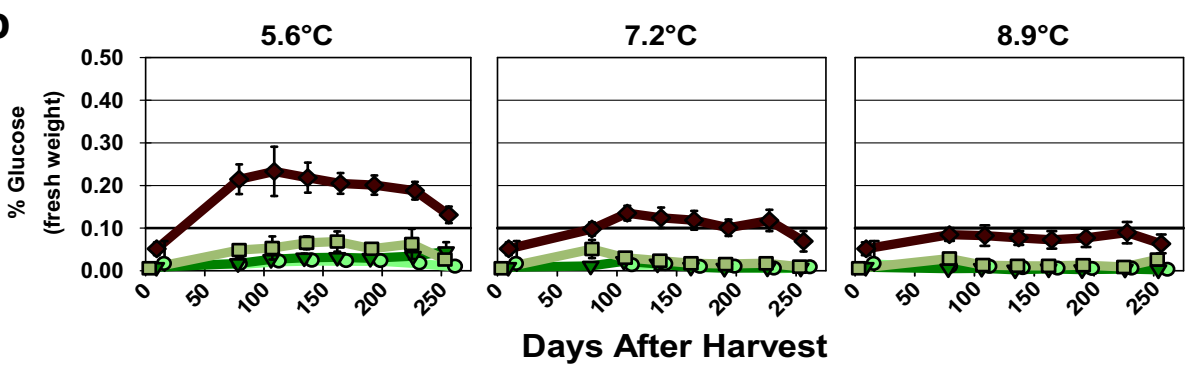

C

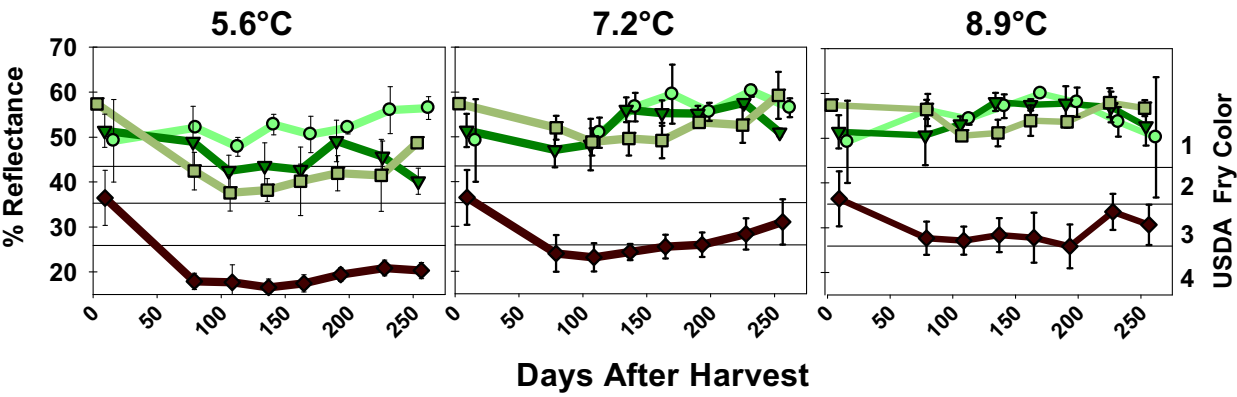

Payette Russet

$\circ 12-13 \longrightarrow 13-14 \longrightarrow$ 14-15

Russet Burbank

12-15
The ability to maintain low levels of both reducing sugars and Asn regardless of storage temperatures is believed to be the basis for the low acrylamide forming potential of Payette Russet tubers that was observed over 4 years of the National Fry Processing Trial (NFPT) (Fig. 5). In those 4 years of the NFPT, Payette Russet had significantly reduced levels of acrylamide, with an $81 \%$ reduction in acrylamide concentrations in French fries relative to both check cultivars following 8 months of storage at $9{ }^{\circ} \mathrm{C}$. In those same trials, where there was also a storage regime of just one month with a briefer duration for reducing sugar concentrations in tubers to increase due to cold-sweetening, acrylamide concentrations of Payette Russet relative to Russet Burbank and Ranger Russet were still reduced by $64 \%$ and $52 \%$ respectively.

\section{Specific Gravity}

The mean specific gravities of tubers of Payette Russet in fullseason trials in Idaho and other western sites ranged between
1.088 to 1.091 which was greater than values for Ranger Russet and Russet Burbank in the same trials (Tables 1, 2, and 3). Specific gravity values of this magnitude are acceptable for fry processing based on industry feedback during NFPT meetings, with 1.084 being ideal, with values within a range of 1.080-1.095 considered acceptable.

\section{Tuber Defects}

Using a five point rating scale with a value of 5.0 indicative of no defects, Payette Russet was rated $\geq 4.7$ for both growth cracks and second growth during 4 years of evaluations in both the Tri-State and Western Regional Potato Variety Trials (Table 6). This low incidence of external defects is similar to observations for Ranger Russet. However, Russet Burbank had a greater incidence of both growth cracks and second growth which contributed to its lower U.S. No. 1 yield relative to Payette Russet. Net necrosis/vascular discoloration in Payette Russet were lower than either check cultivar. Payette Russet is intermediate between Ranger Russet and 

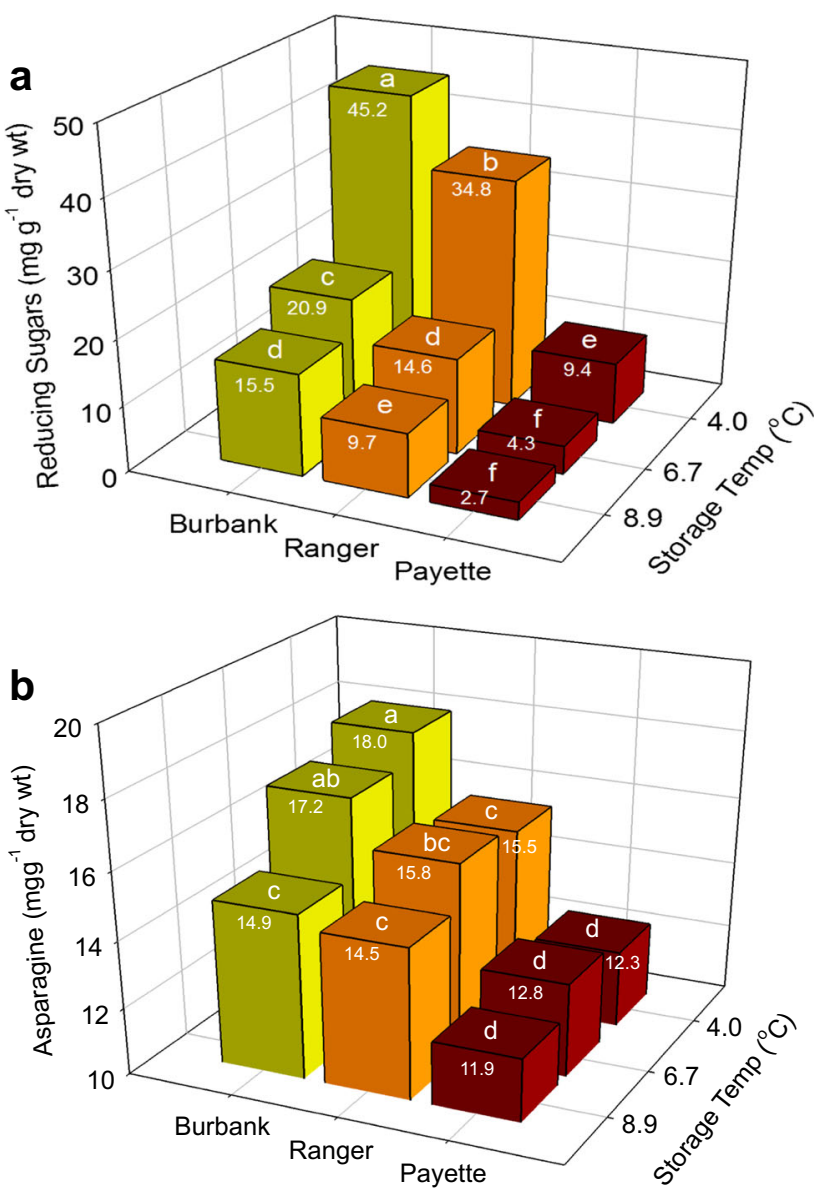

Fig. 4 Reducing sugar (a) and free asparagine (b) concentrations (acrylamide precursors) in Russet Burbank, Ranger Russet and Payette Russet tubers following 60 days of storage at three temperatures. Data are averages of tubers from the Western Regional Trials conducted at Othello, WA from 2012 to 2014. Letters indicate mean separation by LSD $(P<0.05)$. Each bar represents 108 tubers (3 replicates of 12 tubers per season). On a $\mathrm{mg} \mathrm{g}^{-1}$ dry weight basis, reducing sugar concentrations equate approximately to the following USDA French fry colors: $<13$, USDA $0 ; 14-20$, USDA $1 ; 21-27$, USDA $2 ; 27-37$, USDA $3 ;>37$, USDA 4. Fry quality (color) becomes unacceptably dark ( $\geq$ USDA 3 ) when reducing sugar levels exceed approximately $27 \mathrm{mg} \mathrm{g}^{-1}$ dry weight. Reducing sugars were determined enzymatically as detailed in Zommick et al. (2014b). Asparagine was analyzed via gas chromatography as outlined in Kumar et al. (2015)

Russet Burbank for incidence of hollow heart/brown center, whereas it was more prone to shatter bruise and internal brown spot than either of the check cultivars. The higher incidence of internal brown spot in Payette Russet was primarily attributable to the Hermiston, OR trial site in the southern Columbia Basin, where it was observed consistently across years (Table 6). Susceptibility of Payette Russet to blackspot bruise was similar to Russet Burbank and was reduced relative to Ranger Russet. Over a three year period, average tuber weight loss of Payette Russet averaged across nine months storage at temperatures of $5.6^{\circ}, 7.2^{\circ}$, and $8.9^{\circ} \mathrm{C}$, was considerably higher at $14.1 \%$ relative to the $7.7 \%$ tuber weight loss observed for Russet Burbank (Table 6).

\section{Disease and Pest Responses}

Methodology Evaluations of disease responses for Payette Russet were based on data collected from replicated field trials conducted for a minimum of two years. Verticillium wilt (Verticillium dahlia) evaluations were conducted at Aberdeen, ID using naturally occurring inocula and protocols described by Corsini et al. (1988) with additional data provided from National Verticillium Wilt resistance trials conducted by Dr. Shelley Jansky in Wisconsin. Common scab (Streptomyces scabies) was evaluated on tubers collected from three replicates from field trials arranged in a randomized complete block (RCB) using naturally occurring inocula at Aberdeen, ID. Early blight (Alternaria solani) foliar evaluations were conducted at Aberdeen, ID and were based on visual estimates of the amount of leaf area infected in three replicate plots of a RCB design.

Soft rot evaluations were conducted at Aberdeen, ID on tubers washed at harvest and stored for approximately 3 months at $10{ }^{\circ} \mathrm{C}$. These stored tubers were then tumbled for $30 \mathrm{~s}$ in a semi-abrasive, carpet lined cement mixer. Tubers were then dipped for $5 \mathrm{~min}$ in a $5 \times 10^{4}$ cells $/ \mathrm{ml}$ solution of Pectobacterium atrosepticum and placed in a mist chamber with $100 \% \mathrm{RH}$ at $18{ }^{\circ} \mathrm{C}$. When tubers were sufficiently rotted ( $\sim 1$ week) they were removed and scored on a $1-5$ scale with 5 being more than $50 \%$ rot. Fusarium dry rot evaluations were performed as described by Corsini and Pavek (1986) with evaluations also being conducted at the University of Idaho, Kimberly Research and Extension Center as described by Schisler et al. (2000).

Late blight (Phytophthora infestans) field evaluations were conducted at Corvallis, OR as described by Mosley et al. (2003) and in the National Late Blight Germplasm Evaluation Trials as described by Haynes et al. (2002). Evaluations of Potato leafroll virus (PLRV), Potato virus $Y$ (PVY), and Potato virus $X(\mathrm{PVX})$ resistances were conducted at Kimberly, ID using virus-infected spreader rows as described by Corsini et al. (1994).

Corky ringspot (Tobacco rattle virus) evaluations were conducted on station at the Irrigated Agriculture Research and Extension Center, Washington State University, Prosser, WA in the Lower Yakima Valley using protocols described by Brown et al. (2000, 2009). Potato mop-top virus(PMTV) evaluations were also conducted in the Columbia Basin with the screening consisting of six replicates of 5- hill plots of each entry, with 20 tubers of each replicate being cut longitudinally into 4 wedges and evaluated for disease incidence and severity. A select number of tubers were also evaluated using RT PCR to confirm presence of PMTV and to eliminate the possibility that tuber symptoms were caused by Tobacco rattle virus.

Three replicate bacterial ring rot evaluations were conducted by Dr. Rob Davidson, Colorado State University (retired) 
Table 4 Postharvest ratings of Payette Russet, Ranger Russet, and Russet Burbank following seven months of storage (three months at $8.9^{\circ} \mathrm{C}$ and four months at $6.7^{\circ} \mathrm{C}$ ) from 2011 to 2014

\begin{tabular}{|c|c|c|c|c|c|c|c|c|c|c|}
\hline \multirow[b]{2}{*}{ Location/Cultivar } & \multicolumn{3}{|c|}{ Photovolt Reading ${ }^{\mathrm{a}}$} & \multirow{2}{*}{$\begin{array}{l}\text { Difference }^{\mathrm{b}} \text { : } \\
\text { Stem -vs- Bud }\end{array}$} & \multirow{2}{*}{$\begin{array}{l}\text { USDA Color } \\
\text { rating }^{\mathrm{c}}\end{array}$} & \multicolumn{3}{|c|}{$\%$ Reducing sugars ${ }^{\mathrm{d}}$} & \multicolumn{2}{|c|}{ Tuber Sprouting $^{\mathrm{f}}$} \\
\hline & Stem & Bud & Avg. & & & Stem & Bud & Avg. & $\%$ of Tubers & Sprout Length (mm) \\
\hline \multicolumn{11}{|l|}{ Washington } \\
\hline Payette Russet & 50.6 & 52.1 & $51.3 \mathrm{a}^{\mathrm{e}}$ & $4.4 \mathrm{a}$ & 0.0 & 0.54 & 0.54 & 0.54 & $20.5 \mathrm{ab}$ & 3.2 \\
\hline Ranger Russet & 27.4 & 39.2 & $33.3 b$ & $12.7 \mathrm{~b}$ & 1.0 & 1.67 & 0.77 & 1.22 & $93.3 \mathrm{c}$ & 15.9 \\
\hline Russet Burbank & 25.7 & 41.7 & $33.7 b$ & $16.1 \mathrm{~b}$ & 1.3 & 1.88 & 0.69 & 1.28 & $6.7 \mathrm{a}$ & 0.8 \\
\hline \multicolumn{11}{|l|}{ Idaho } \\
\hline Payette Russet & 48.8 & 51.2 & $50.0 \mathrm{a}$ & $3.3 \mathrm{a}$ & 0.0 & 0.55 & 0.53 & 0.54 & $0 \mathrm{a}$ & 0.0 \\
\hline Ranger Russet & 28.4 & 39.4 & $33.9 b$ & $11.2 \mathrm{~b}$ & 1.0 & 1.55 & 0.76 & 1.16 & $65.0 \mathrm{~b}$ & 7.1 \\
\hline Russet Burbank & 24.4 & 42.1 & $33.2 \mathrm{~b}$ & $18.7 \mathrm{c}$ & 1.7 & 2.05 & 0.68 & 1.37 & $0 \mathrm{a}$ & 0.0 \\
\hline \multicolumn{11}{|l|}{ Oregon } \\
\hline Payette Russet & 46.2 & 51.8 & $49.0 \mathrm{a}$ & $8.0 \mathrm{a}$ & 0.0 & 0.62 & 0.54 & 0.58 & $46.8 b$ & 3.2 \\
\hline Ranger Russet & 26.0 & 39.7 & $32.8 b$ & $13.7 \mathrm{~b}$ & 1.3 & 1.83 & 0.75 & 1.29 & $88.3 \mathrm{c}$ & 17.5 \\
\hline Russet Burbank & 22.1 & 41.2 & $31.7 \mathrm{~b}$ & $19.2 \mathrm{c}$ & 2.0 & 2.37 & 0.68 & 1.53 & $3.3 \mathrm{a}$ & 0.8 \\
\hline
\end{tabular}

All post-harvest evaluations and ratings were conducted at Pullman, WA using tubers harvested from 2011 to 2104 trials at Aberdeen, ID, Hermiston, $\mathrm{OR}$, and Othello, WA

${ }^{a}$ Fries $(0.95 \mathrm{~cm} \times 2.87 \mathrm{~cm})$ were fried at $191{ }^{\circ} \mathrm{C}$ for $3.5 \mathrm{~min}$ and color was measured with a Photovolt reflectance meter (model 577 , Photovolt Instruments Inc., Minneapolis, MN) within three minutes of removal from oil. A Photovolt light reflectance reading of $\leq 19$ is considered unacceptably dark (see note 3 below)

${ }^{\mathrm{b}}$ A difference $\geq 9$ Photovolt light reflectance units between bud and stem end constitutes non-uniform fry color. Values represent an average of actual Photovolt differences in each of four years and therefore do not relate directly to averaged stem and bud values listed in the table

${ }^{\mathrm{c}}$ USDA color $(0=$ light and $4=$ dark $)$ ratings were assigned based upon Photovolt light reflectance readings of the darkest ends of fries (typically stem ends); Photovolt readings $\geq 31=$ USDA 0, 25-30 = USDA 1, 20-24 = USDA 2, 15-19=USDA 3, $\leq 14=$ USDA 4. Data are averaged over years

${ }^{\mathrm{d}}$ Glucose + Fructose (dry matter basis) were estimated from an algorithm relating fry color to percent reducing sugars assayed by the dinitrophenol method of Ross (1959). Acceptable values for processing are $\leq 2.6 \%$

${ }^{\mathrm{e}}$ Within a state, means followed by different letters differed significantly (LSD, $\left.P<0.05\right)$

${ }^{\mathrm{f}}$ Sprouting was measured following approximately 3 months storage at $8.9^{\circ} \mathrm{C}$

in Center, Colorado in 2012 and 2013, and at Kimberly, ID in 2015 using a pathogenic rifampicin-resistant strain (CIC31) of Clavibacter michiganensis subsp. Sepedonicus. Freshly cut seed pieces were dipped in a bacterial solution and placed in paper sacks. Seed pieces were planted the next day in a RCB design with 7 inoculated seed pieces planted next to 7 noninoculated seed pieces for control plots. Foliar symptoms were recorded weekly beginning mid-season.

Disease Response Relative to industry standard cultivars, Payette Russet is notable for its resistance to foliar and tuber late blight and extreme resistance to PVY (Tables 7, 8, 9, and 10). Resistance to common scab is comparable to that of Russet Burbank, with Payette Russet also displaying moderate resistance to Verticillium wilt, early blight, and corky ringspot. Payette Russet is considered susceptible to PLRV and accompanying tuber net necrosis, PVX, potato mop-top virus, and dry rot (F. sambucinum); levels of susceptibility to these pests and diseases are given in Table 7.

The AUDPC for foliar late blight of Payette Russet was consistently lower than values observed for Ranger Russet and Russet Burbank over three years of inoculated field evaluations with the US- 8 genotype of $P$. infestans, with Payette Russet also showing no tuber infection across all three years (Table 8). Resistances to genotypes US-22 and US-23 of $P$. infestans were also displayed by Payette Russet in National Potato Late Blight trials with AUDPC values consistently among the lowest across years and sites (Table 9).

The late blight resistance exhibited by Payette Russet derives from its Polish ancestry, with Polish germplam also having contributed to the late blight resistance of Tri-State cultivars Defender and Palisade Russet (Novy et al., 2006, 2012). However, while Defender and Palisade Russet had common ancestry through Polish family KSA-195, this family is not present in the ancestry of Payette Russet. A review of the Polish pedigree of Payette Russet through four generations identifies no shared breeding clones or cultivars with those ancestries of Defender and Palisade Russet. However, since all three cultivars derive from germplasm provided by the Polish Plant Breeding and Acclimatization Institute (IHAR), it is likely that shared ancestry may exist beyond four generations. 
Table 5 Mean postharvest ratings ${ }^{\mathrm{a}}$ of Payette Russet, Ranger Russet, and Russet Burbank in full-season trials in the 20,011-2014 Tri-State and Western Regional Potato Variety Trials

\begin{tabular}{lllll}
\hline & Washington & Idaho & Oregon & Mean \\
\hline Payette Russet & 34.8 & 34.1 & 34.7 & 34.5 \\
Ranger Russet & 26.1 & 27.6 & 28.9 & 27.5 \\
Russet Burbank & 18.0 & 15.1 & 13.9 & 15.7 \\
\hline
\end{tabular}

Post-harvest evaluations and ratings were conducted at Pullman, WA using tubers produced in trials at Aberdeen, ID, Hermiston, OR, and Othello, WA

${ }^{\text {a }}$ Values were assigned based on the sum of individual ratings for fry color from the field, after storage at 8.9 and $6.7^{\circ} \mathrm{C}(60$ days $)(0-5$ scale, $1=$ dark, $5=$ light), reducing sugar concentrations following 60 days storage at 8.9 and $6.7^{\circ} \mathrm{C}(1-5$ scale, $1=$ high, $5=$ low $)$, specific gravity $(0-5$ scale, $1=$ low, $5=$ high), and average sensory evaluations by taste panels (1-5 scale, 5 = best). With three fry color ratings (field, $8.9^{\circ}$ and $6.7^{\circ} \mathrm{C}$ ), two reducing sugar concentration ratings $\left(8.9\right.$ and $6.7^{\circ} \mathrm{C}$ ), and one rating each for specific gravity and sensory evaluation, a maximum rating of 35 could be obtained if the most favorable score (5) is given in each of the seven total ratings. An additional 3 points could be added for high fry color uniformity between stem and bud ends, resulting in a maximum possible value of 38 . Higher values are indicative of superior post-harvest attributes

Payette Russet also has been shown to have the molecular markers YES3 (Song and Schwarzfischer, 2008) and STM003 (Milbourne et al., 1998; Valkonen et al., 2008), closely linked with the PVY resistance gene $R y_{\text {sto }}$ derived from Solanum stoloniferum. This gene is most likely contributed by the Polish ancestors from IHAR, Mlochow, Poland, with this program being the recipient of germplasm with $R y_{\text {sto }}$ from the the potato breeder Dr. Hans Ross of the Max Planck Institute in Cologne, Germany. Extreme resistance to PVY is conferred by $R y_{\text {sto }}$ with no infection observed over years in field screening trials, whereas significantly higher levels of PVY infection were observed in Ranger Russet and Russet Burbank which lack the gene (Table 10). The presence of $R y_{\text {sto }}$ is associated with resistance to all strains of PVY (Song and Schwarzfischer 2008; Valkonen et al., 2008). Inoculations of Payette Russet with three strains of PVY (O, NTN, N:O/NWi) at Aberdeen, ID produced no infection, corroborating reports of extreme resistance to all strains. The resistance conferred by $R y_{\text {sto }}$ and other genes for extreme resistance to PVY has been described as durable (Solomon-Blackburn and Barker, 2001; Bradshaw 2007).

Payette Russet showed typical foliar symptoms of bacterial ring rot (BRR) under Colorado conditions, with plants showing first symptoms at 62 and 74 days after planting in 2012 and 2013, respectively. Russet Burbank in the same Colorado trials showed first symptoms at 60 and 62 days after planting. Foliar symptoms of BRR in Payette Russet in both years included dwarfing of plants and rosette growth, interveinal chlorosis and necrosis, leaf margin necrosis, and whole stem wilt. Ten tubers from each of two replicates (twenty tubers total) were evaluated in each year at harvest for symptoms typical of BRR infection. No tubers of Payette Russet in either year were identified as having BRR internal/external symptoms; Russet Burbank also showed no tuber symptoms 2012, with one tuber displaying external symptoms of BRR in 2013. In the 2015 Kimberly, ID trial, readings of bacterial ring rot infection were first taken 100 days after planting, with Payette Russet displaying leaf margin necrosis, interveinal chlorosis, and whole stem wilt. Clavibacter michiganensis subsp. Sepedonicus (Cms) was detected by PCR in stems from all three replicates of Payette Russet at harvest. In addition, 1 tuber out of 169 harvested had both external and internal symptoms of bacterial ring rot. Russet Burbank in the same

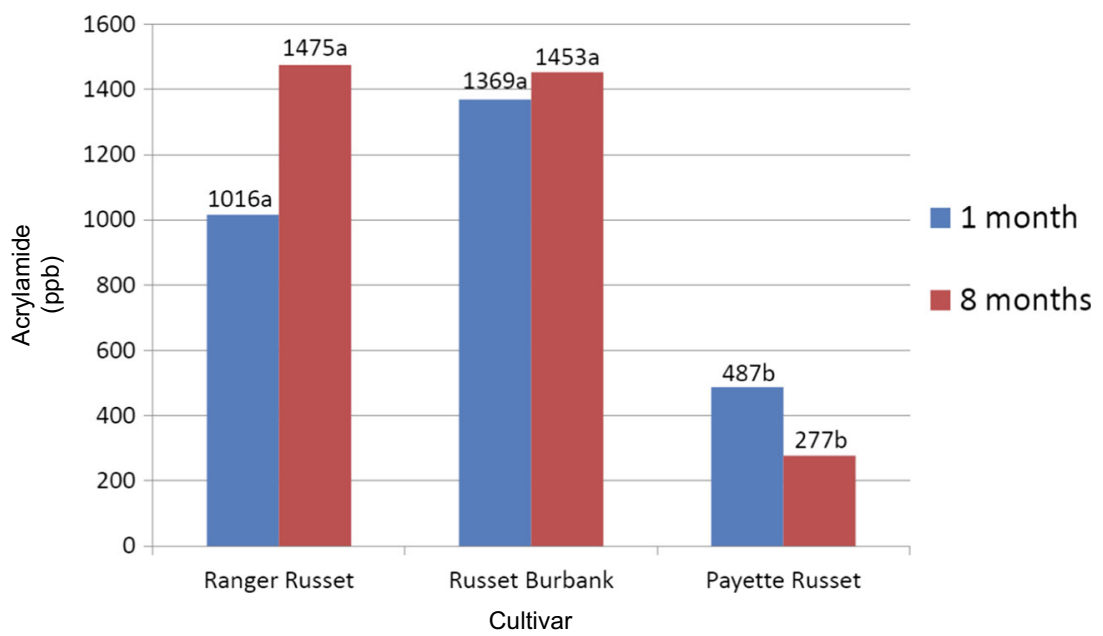

Fig. 5 Average acrylamide concentration ( $p p b$ ) of French fries of Payette Russet, Ranger Russet, and Russet Burbank made from harvested tubers from National Fry Processing Trials conducted in Idaho, North Dakota, Washington and Wisconsin, 2011-2014. Fries were made from tubers following 1 and 8 months storage at $9{ }^{\circ} \mathrm{C}$ as described by Wang et al.
(2016). Wisconsin trial data for 1 month and 8 month storage in 2011 and 2013 were not included in the analyses due to an incomplete data set with values for all three cultivars not being available. Mean values followed by the same letter are not significantly different from one another $(P<0.05)$ based on Student's t-test 
Table 6 Evaluation of internal and external defects of Payette Russet, Ranger Russet, and Russet Burbank in Tri-State and Western Regional Trials (2011-2014)

\begin{tabular}{|c|c|c|c|c|c|c|c|c|}
\hline Cultivar & $\begin{array}{l}\text { Growth } \\
\text { cracks }^{\mathrm{a}, \mathrm{c}}\end{array}$ & $\begin{array}{l}\text { Second } \\
\text { growth }^{\mathrm{a}, \mathrm{d}}\end{array}$ & $\begin{array}{l}\text { Shatter } \\
\text { bruise }^{\mathrm{a}, \mathrm{e}}\end{array}$ & $\begin{array}{l}\text { Hollow } \\
\text { heart/BC }{ }^{b, f}\end{array}$ & $\begin{array}{l}\% \text { Internal } \\
\text { brown Spot }{ }^{\mathrm{g}}\end{array}$ & $\begin{array}{l}\% \text { Net necrosis/ } \\
\text { Vasc. discol. }\end{array}$ & $\begin{array}{l}\text { Blackspot } \\
\text { bruise }^{\mathrm{a}, \mathrm{i}}\end{array}$ & $\begin{array}{l}\text { Tuber } \\
\text { Weight Loss }\end{array}$ \\
\hline Payette Russet & 4.8 & 4.7 & 3.6 & 1.7 & 6.5 & 2.1 & 4.4 & 14.1 \\
\hline Ranger Russet & 4.5 & 4.5 & 4.4 & 0.4 & 1.6 & 5.8 & 3.8 & n.a. \\
\hline Russet Burbank & 4.0 & 3.7 & 4.2 & 7.1 & 1.8 & 5.9 & 4.2 & 7.7 \\
\hline
\end{tabular}

${ }^{\text {a }}$ Rated using a $1-5$ scale with $1=$ severe and $5=$ none observed

${ }^{\mathrm{b}}$ Rated as the percentage of tubers $>341 \mathrm{~g}$ with hollow heart and brown center

${ }^{c}$ Average of 40 ratings

${ }^{\mathrm{d}}$ Average of 38 ratings

${ }^{\mathrm{e}}$ Average of 34 ratings

${ }^{\mathrm{f}}$ Average of 41 ratings

${ }^{\mathrm{g}}$ Average of 36 ratings

${ }^{\mathrm{h}}$ Average of 29 ratings

${ }^{\mathrm{i}}$ Average of 31 ratings

${ }^{\mathrm{j}}$ Value is percent weight loss following nine months of storage in 2012-2014 (three years of storage data). Value reflects an average across three storage temperatures of 5.6, 7.2 , and $8.9^{\circ} \mathrm{C}$ conducted at Kimberly, ID

plots had no foliar symptoms from the 100 to 122 days after planting evaluations and no symptomatic tubers, but its stems tested positive for $\mathrm{Cms}$ based on PCR.

In summary, Payette Russet has foliar and tuber resistance to late blight, common scab resistance, and extreme resistance to PVY, as well as moderate resistance to Verticillium wilt, early blight, and corky ringspot. It expresses typical foliar symptoms of bacterial ring rot. The assemblage of disease resistances in Payette Russet make it a good candidate for organic production, and for commercial potato growers seeking more sustainable production with reduced pesticide inputs.

\section{Biochemical and Nutritional Characteristics}

Tubers of Payette Russet, Ranger Russet, and Russet Burbank, grown at Aberdeen, ID, were analyzed six weeks after harvest following storage at $7{ }^{\circ} \mathrm{C}$ over a four-year period to assess biochemical and nutritional components (Table 11). The higher specific gravity of Payette Russet was also reflected in a high dry matter percentage of $23.4 \%$, which was $0.9 \%$ and $3.8 \%$ greater than values for Ranger Russet and Russet Burbank, respectively.

Sucrose percentages for Payette Russet were identical to levels observed in Ranger Russet and higher than Russet Burbank, whereas glucose levels were lowest for Payette Russet with concentrations no more than half the check cultivars.

Protein concentrations in tubers of Payette Russet were comparable to Ranger Russet and higher than Russet Burbank. Vitamin C content of Payette Russet was intermediate to those of the check cultivars, with Ranger Russet, known for its high Vitamin C content, having the highest concentration. Total glycoalkaloids for Payette Russet

Table 7 Disease response of Payette Russet relative to Ranger Russet and Russet Burbank ${ }^{\mathrm{a}}$

\begin{tabular}{|c|c|c|c|c|c|c|c|c|c|c|c|c|c|}
\hline \multirow[t]{2}{*}{ Cultivar } & \multirow{2}{*}{$\begin{array}{l}\text { Vert. } \\
\text { Wilt }\end{array}$} & \multirow{2}{*}{$\begin{array}{l}\text { Com. } \\
\text { Scab }\end{array}$} & \multirow{2}{*}{$\begin{array}{l}\text { Early } \\
\text { Blight }\end{array}$} & \multicolumn{2}{|c|}{ Late Blight } & \multicolumn{3}{|c|}{ Viruses } & \multicolumn{3}{|c|}{ Symptoms of Virus Infection } & \multicolumn{2}{|c|}{ Storage Diseases } \\
\hline & & & & Foliar & Tuber & PVX & $\mathrm{PVY}$ & PLRV & $\begin{array}{l}\text { Net } \\
\text { Necrosis }\end{array}$ & $\begin{array}{l}\text { Corky } \\
\text { Ringspot }\end{array}$ & $\begin{array}{l}\text { Potato } \\
\text { Mop-Top }\end{array}$ & $\begin{array}{l}\text { Soft } \\
\text { Rot }\end{array}$ & $\begin{array}{l}\text { Dry } \\
\text { Rot }^{b}\end{array}$ \\
\hline Payette R. & MR & $\mathrm{R}$ & MR & $\mathrm{R}$ & $\mathrm{R}$ & MS & ER & $\mathrm{S}$ & $\mathrm{S}$ & MR & $\mathrm{S}$ & MS & $\mathrm{S} / \mathrm{R}$ \\
\hline Ranger R. & MR & $\mathrm{S}$ & MS & $\mathrm{S}$ & VS & MR & S & $\mathrm{S}$ & MS & S & MS & MR & MS \\
\hline R.Burbank & $\mathrm{S}$ & $\mathrm{R}$ & MS & $\mathrm{S}$ & $\mathrm{S}$ & $\mathrm{S}$ & S & $\mathrm{S}$ & $\mathrm{S}$ & S & MS & MS & S/MS \\
\hline
\end{tabular}

${ }^{a}$ Responses of Payette Russet and check cultivars to diseases were based on a minimum of 2 years of controlled field evaluations. Responses were defined as extremely resistant (ER), resistant (R), moderately resistant (MR), moderately susceptible (MS), susceptible (S), and very susceptible (VS). Disease evaluations were conducted at Aberdeen, ID with the exceptions of PVX, PVY, PLRV, and net necrosis evaluations being conducted at Kimberly, ID, and corky ringspot and potato mop-top evaluations being conducted at Prosser, WA and Grant County, WA, respectively

${ }^{\mathrm{b}}$ Ratings are indicative of response to infection by Fusarium sambucinum/F. solani var. coeruleum. If only one value is shown (e.g., Ranger Russet), then the variety is considered as having equivalent response to both Fusarium species 
Table 8 Foliar and tuber data for late blight infection of Payette Russet, Ranger Russet, and Russet Burbank from US-8 inoculated trials conducted at Corvallis, OR from 2011 to 2013, with no fungicides applied for the control of late blight

\begin{tabular}{lllllllll}
\hline & \multicolumn{2}{l}{ AUDPC $^{\mathrm{a}}$} & & & \multicolumn{3}{l}{ Tuber \% $^{\mathrm{b}}$} \\
\cline { 2 - 4 } \cline { 7 - 9 } & 2011 & 2012 & 2013 & & 2011 & 2012 & 2013 \\
\hline Payette Russet & $557 \mathrm{a}$ & $121 \mathrm{a}$ & $736 \mathrm{a}$ & $0 \mathrm{a}$ & $0 \mathrm{a}$ & $0 \mathrm{a}$ \\
Ranger Russet & $1198 \mathrm{~b}$ & $1510 \mathrm{~b}$ & $1363 \mathrm{~b}$ & & $18 \mathrm{~b}$ & $45 \mathrm{~b}$ & $75 \mathrm{~b}$ \\
Russet Burbank & $1180 \mathrm{~b}$ & $1459 \mathrm{~b}$ & $1357 \mathrm{~b}$ & & $5 \mathrm{a}$ & $8 \mathrm{a}$ & $75 \mathrm{~b}$
\end{tabular}

Mean values followed by the same letter are not significantly different from one another $(\mathrm{P}<0.05)$ based on Student's t-test

${ }^{\mathrm{a}}$ Foliar area under the disease progress curve

${ }^{\mathrm{b}}$ Percent tuber rot resulting from infection by late blight

were $8.6 \mathrm{mg} / 100 \mathrm{~g}$ tuber fresh weight, which was higher than those of the check cultivars, but far below the critical threshold of $20 \mathrm{mg} / 100 \mathrm{~g}$ tuber fresh weight.

\section{Management}

A number of studies on Payette Russet management have been conducted in southern Idaho and the Columbia Basin. Results of these studies may provide growers in these and other production regions with the basis for developing appropriate management guidelines for their locale.

\section{Southern Idaho}

Planting Payette Russet is late maturing and requires full season production for maximum yield and quality in southern Idaho. Optimal seed size for Payette Russet is about 55 to $85 \mathrm{~g}$. Dry rot potential of seed lots should be determined and seed should be treated with an effective fungicide when needed. Planting depth should be 15 to $20 \mathrm{~cm}$ from the top of the seed piece to the top of the hill. Seed piece spacing should be 23 to $25 \mathrm{~cm}$ for fresh market use, but spacing should be increased to 25 to $28 \mathrm{~cm}$ for processing use, when planted within rows spaced 86-91 cm apart. Because of its slow emergence,
Payette Russet seed should be treated and planted in soil with optimal temperature $\left(7\right.$ to $\left.13{ }^{\circ} \mathrm{C}\right)$ to facilitate early emergence and minimize the potential for soft rot decay.

Herbicide Management Payette Russet has exhibited good resistance to the herbicide metribuzin when applied at labeled rates.

Nutrient Management Total seasonal amounts of soil $\mathrm{N}$ plus fertilizer N for Payette Russet should be 180-200 kg N/ha for a $45 \mathrm{t} / \mathrm{ha}$ yield potential, $210-230 \mathrm{~kg} \mathrm{~N} / \mathrm{ha}$ for a $56 \mathrm{t} / \mathrm{ha}$ yield potential, and $240-260 \mathrm{~kg} \mathrm{~N} / \mathrm{ha}$ in areas with a $67 \mathrm{t} / \mathrm{ha}$ yield potential. Petiole nitrate levels should be about 18,000 $20,000 \mathrm{ppm}$ at the end of tuber initiation and decrease to 12,000 to $15,000 \mathrm{ppm}$ during mid-bulking and to 6000 to 8000 ppm during late bulking. To promote skin set, $\mathrm{N}$ applications should be completed at least 30 days prior to harvest. Phosphorus and potassium fertilizer recommendations for Russet Burbank should be followed until recommendations for Payette Russet are developed and available.

Irrigation Seasonal available soil moisture (ASM) should be maintained within the range of 70 to $85 \%$ for optimal yield and quality. Plant water uptake decreases in late August as vines senesce, so irrigation application rates need to be adjusted to maintain ASM at about $60 \%$ to $70 \%$ to avoid developing excessively wet soil conditions that promote disease. Low soil moisture conditions appreciably below $60 \%$ ASM should be avoided during tuber maturation and harvest to minimize tuber dehydration and blackspot bruise.

Vine Kill and Harvest Irrigation rates should be gradually reduced during the last two weeks prior to vine kill to allow tuber hydration to decrease to an intermediate level during skin set. Vine kill two to three weeks before harvest to maximize skin set and harvest at pulp temperatures below $15^{\circ} \mathrm{C}$ to reduce storage disease potential. Payette Russet is susceptible to shatter bruise and therefore should be handled as gently as possible to minimize tuber impact damage. Fusarium dry rot control for tubers in storage can also be facilitated by
Table 9 Foliar late blight data for Payette Russet from three locations of the National Potato Late Blight Trials, 2012-2013. Predominant genotype of Phytophthora infestans at each state trial site is indicated in parentheses

\begin{tabular}{|c|c|c|c|c|c|c|}
\hline & \multicolumn{2}{|c|}{ Michigan (US-22) } & \multicolumn{2}{|c|}{ Oregon (US-8) } & \multicolumn{2}{|c|}{ Pennsylvania (US-23) } \\
\hline & 2012 & 2013 & 2012 & 2013 & 2012 & 2013 \\
\hline AUDPC $^{\mathrm{a}}$ & 28 & 117 & 203 & 736 & 15 & 0 \\
\hline Clone Rank ${ }^{\mathrm{b}}$ & $3 / 37$ & $13 / 26$ & $5 / 37$ & $3 / 26$ & $6 / 37$ & $1 / 26$ \\
\hline AUDPC Minimum at Trial Site & 20 & 0 & 56 & 213 & 6 & 0 \\
\hline AUDPC Median at Trial Site & 200 & 125 & 1179 & 1357 & 127 & 20 \\
\hline AUDPC Maximum at Trial Site & 1483 & 257 & 1803 & 1445 & 924 & 100 \\
\hline
\end{tabular}

${ }^{\text {a }}$ Area under the disease progress curve;

${ }^{\mathrm{b}}$ Rank among number of trial entries, with 1 being the most highly resistant to late blight 
Table 10 Percentage of PVY infected tubers of Payette Russet, Ranger Russet, and Russet Burbank following mechanical inoculation of field plots with PVY, with further aphid vectoring of PVY from virus-infected spreader rows planted in the trial at Kimberly, ID

\begin{tabular}{llcc}
\hline Cultivars & \multicolumn{2}{c}{$\%$ PVY infection in tubers of inoculated plants based on ELISA testing } & 2010 \\
\cline { 2 - 4 } & 2007 & 2009 & $0 \mathrm{a}$ \\
\hline Payette Russet & $0 \mathrm{a}^{\mathrm{a}}$ & $0 \mathrm{a}$ & $95 \mathrm{~b}$ \\
Ranger Russet & $59 \mathrm{~b}$ & $48 \mathrm{~b}$ & $97 \mathrm{~b}$ \\
Russet Burbank & $73 \mathrm{~b}$ & $40 \mathrm{~b}$ & \\
\hline
\end{tabular}

${ }^{\mathrm{a}} \operatorname{LSD} p<0.05$

minimizing tuber skinning and bruising during harvest and subsequent handling.

\section{Columbia Basin of Washington State}

When grown in full-season trials in the Columbia Basin of Washington, Payette Russet typically produces a medium to large tuber size profile, similar to Russet Burbank and Ranger Russet, with gross economic processing returns similar to Ranger Russet, and an average of $\$ 3430$ per hectare greater than Russet Burbank (Table 12). During 2011-15, Payette Russet produced between 8- and 10-tubers per plant when grown in Othello, WA. During the same period, both Ranger Russet and Russet Burbank plants produced 7- to 9-tubers (data not shown). Due to tuber size profile similarities with Ranger Russet and Russet Burbank, it is recommended that Payette Russet seed pieces be sized from 43 to $85 \mathrm{~g}$ and planted in a spatial arrangement common for these varieties into rows spaced $81 \mathrm{~cm}$ apart. Recommended final planting depth is $20 \mathrm{~cm}$ from the top of the hill to the top of the planted seed piece. Due to a non-uniform, rounded shape and nonuniform russeting of skin, Payette Russet does not fit the profile of a fresh-pack variety for the Columbia Basin, with only guidelines for full-season management for processing presented. Early-harvest ( 100-120 days after planting (DAP) production of Payette Russet is not recommended in the Columbia Basin due to low early yields and economic return (Pavek and Knowles 2014). French fry processors should note that when Payette Russet is grown in the Columbia Basin of Washington, it produces tubers with a low length to width ratio ( $\sim 1.41$, close to round) resulting in a lower French fry yield relative to Russet Burbank and Ranger Russet (Pavek and Knowles 2014). By comparison, length to width ratios for Payette Russet at Aberdeen, ID ranged from 1.67 to 1.71. Ongoing investigations into the application of GA to seed for more rapid plant emergence in Payette Russet may also increase the tuber length to width ratio of its tubers in the Columbia Basin with a corresponding increase in yield of fries (Knowles et al. 2016).

\section{Late Harvest (Full Season) Production - Process Market} For full season growth with a harvest between September and October ( $>140$ DAP), seed should be spaced $25 \mathrm{~cm}$ apart inrow. Nitrogen fertilizer management should be similar to or slightly higher than that used for Russet Burbank. Growers should strive to keep their petiole $\mathrm{NO}_{3}-\mathrm{N}$ concentrations at

Table 11 Biochemical analyses of Payette Russet, Ranger Russet, and Russet Burbank tubers from Tri-State and Western Regional Trials (2011-2014) conducted at Aberdeen, ID

\begin{tabular}{|c|c|c|c|c|c|c|}
\hline Cultivar & Dry matter (\%) & $\begin{array}{l}\text { Sucrose }^{c} \\
\left(\% \mathrm{FWB}^{\mathrm{b}}\right)\end{array}$ & $\begin{array}{l}\text { Glucose }^{\mathrm{c}} \\
\left(\% \mathrm{FWB}^{\mathrm{b}}\right)\end{array}$ & $\begin{array}{l}\text { Protein }^{\mathrm{d}} \\
\left(\% \mathrm{DWB}^{\mathrm{b}}\right)\end{array}$ & $\begin{array}{l}\text { Vitamin } \mathrm{C}^{\mathrm{e}} \\
\left(\mathrm{mg} / 100 \mathrm{~g} \mathrm{FWB}^{\mathrm{b}}\right)\end{array}$ & $\begin{array}{l}\text { Total Glycoalkaloids }{ }^{\mathrm{f}} \\
\left(\mathrm{mg} / 100 \mathrm{~g} \mathrm{FWB}^{\mathrm{b}}\right)\end{array}$ \\
\hline Payette Russet & 23.4 & 0.18 & 0.03 & 5.8 & 21.6 & 8.6 \\
\hline Ranger Russet & 22.5 & 0.18 & 0.06 & 5.2 & 30.9 & 4.3 \\
\hline Russet Burbank & 19.6 & 0.14 & 0.08 & 4.7 & 18.9 & 3.0 \\
\hline
\end{tabular}

\footnotetext{
${ }^{\text {a }}$ Analyses were conducted on freeze-dried tuber tissue at Aberdeen, ID; tissue was taken from tubers stored at $7.2{ }^{\circ} \mathrm{C}$ for six weeks following their harvest

${ }^{\mathrm{b}}$ FWB $=$ Fresh Weight Basis; DWB = Dry Weight Basis; Sucrose and glucose values of $0.15 \%$ and $0.10 \%$ respectively are maximum values for acceptable fry color in this evaluation, with glucose being the greater contributor to fry color

${ }^{\mathrm{c}}$ Sugar concentrations were calculated according to: Glucose and sucrose measurements in potatoes, Application Note No. 102, Scientific Division, Yellow Springs Instrument Co., Yellow Springs, Ohio 45,387

${ }^{\mathrm{d}}$ Protein content was determined using a Coomassie blue protein assay developed from the protocol of Bradford (1976)

${ }^{\mathrm{e}}$ Vitamin C (ascorbic acid) content in tubers was determined using a microfluorometric method detailed in the Official Methods of Analysis Handbook, 14th edition, sections 43.069-43.075

${ }^{\mathrm{f}}$ Total glycoalkaloids was determined using the protocol of Bergers (1980)
} 
Table 12 Gross economic return ( $\$ /$ ha) for Payette Russet, Ranger Russet, and Russet Burbank in full season trials ( 150 DAP) in the Columbia Basin of Washington for the French fry process market. Values represent averages from 2011 to 14

\begin{tabular}{ll}
\hline Cultivar & Gross Economic Return $\left(\$ / \mathrm{ha}^{\mathrm{a}}\right)$ \\
\hline Payette Russet & $13,910 \mathrm{a}$ \\
Ranger Russet & $13,520 \mathrm{a}$ \\
Russet Burbank & $10,480 \mathrm{~b}$ \\
${\text { - } \text { value }^{b}}^{b}$ & $<0.0001$
\end{tabular}

${ }^{\text {a }}$ Process market (French fry) gross return per hectare was calculated using methods from Pavek and Knowles (2016). Production cost per hectare not applied

${ }^{\mathrm{b}}$ Significance determined using Fisher's Protected LSD Test

the end of tuber initiation (about 60 DAP) above $26,000 \mathrm{ppm}$ and total inorganic soil $\mathrm{N}$ above $100 \mathrm{~kg} \mathrm{~N} / \mathrm{ha}$, between 23,000 to $25,000 \mathrm{ppm}$ at early bulking (80-90 DAP) and between 10,000 to $13,000 \mathrm{ppm}$ at $100 \mathrm{DAP}$, and 8000 to 10,000 at late bulking (approximately 125 DAP). During late bulking, total inorganic soil $\mathrm{N}$ should be below $55 \mathrm{~kg} \mathrm{~N} / \mathrm{ha}$. Management guidelines for nutrients other than $\mathrm{N}$ have not been established for Payette Russet. Therefore, it is recommended that growers follow local nutrient management recommendations for Russet Burbank (Lang et al. 1999) until new guidelines for Payette Russet become available.

Irrigation Management ASM should be maintained between $65 \%$ and $85 \%$ from full emergence until mid-bulking. At late bulking or as vines senesce, ASM should be reduced to $55 \%$ to $65 \%$.

\section{Storage Management}

Payette Russet has excellent cold-sweetening resistance as previously outlined in the section Tuber Sugars and Fry Color, and storage temperature recommendations for frozen processing are $5.6-7.2^{\circ} \mathrm{C}$, which is lower than normal storage temperatures for standard varieties such as Russet Burbank. For fresh market or dehydration processing, Payette Russet can be stored at $5.6{ }^{\circ} \mathrm{C}$ or potentially even lower. Treatment for sprout inhibition with CIPC should be made after wound healing, but within the first two months of storage to reduce sprouting throughout long term storage.

Over a three year period (2012-14), tubers of Payette Russet and Russet Burbank were evaluated for response to Fusarium dry rot at Kimberly, ID as described by Schisler et al. (2000). The three year mean percentage of tissue decay in this $F$. sambucinum-inoculated study following 3 months of storage at $7.2{ }^{\circ} \mathrm{C}$ was $54 \%$ for Payette Russet and $31 \%$ for Russet Burbank. The percent incidence of potatoes with greater than $5 \%$ decay was also significantly higher in Payette Russet (97\%) than in Russet Burbank (78\%).
Tuber weight loss (Table 6) and Fusarium dry rot are factors that can impact the successful long term storage of Payette Russet, and as outlined in production management, efforts should be made to mitigate tuber skinning during harvest, which can concurrently reduce subsequent tuber weight loss and infection by Fusarium spp.

Additional details regarding storage management of Payette Russet can be found in the University of Idaho Extension publication: Storage Management of Payette Russet Potatoes. This document was published in January of 2016 and can be freely accessed at: http://www.cals. uidaho.edu/edComm/pdf/CIS/CIS1220.pdf (accessed on July 6, 2016).

\section{Seed Availability}

In 2015, certified seed of Payette Russet was available from potato seed growers in Idaho, Nebraska, and Wisconsin. Small amounts of seed for research purposes can be obtained by contacting Richard Novy or Jonathan Whitworth, USDAARS, Aberdeen, ID. Pathogen-free tissue culture plantlets of Payette Russet are also maintained by Jenny Durrin, Director of the Nuclear Seed Potato Program, University of Idaho, Moscow, ID. Plant variety protection (PVP) certificate (\#201,600,026) has been granted for Payette Russet.

Acknowledgments The authors thank Margaret Bain, Todd Carter, Mel Chapel, Jeanne Debons, Lorie Ewing, Mary Jo Frazier, Nora Fuller, Darren Hall, Mark Fristad, Zach Holden, Chelsey Lowder, Charlene Miller, Lura Schroeder, Steve Wheeler (deceased), and Lynn Woodell for their contributions to the development and release of Payette Russet, as well our collaborators in the Western Regional Potato Variety Trials, the National Fry Processing Trial, and the Idaho, Washington, and Oregon potato commissions. Thanks as well to Kathy Haynes, USDAARS, Beltsville, MD for her review of this manuscript prior to publication. We also thank our industry cooperators for their substantial contribution to this research effort, and to Dr. Rob Davidson for his evaluation of the response of Payette Russet to bacterial ring rot infection. Development of Payette Russet was partially funded by USDA/NIFA (Potato Breeding Research and SCRI [Grant \#2011-51181-30629]), the Northwest Potato Research Consortium, and by contributions from the potato processing industry to the National Fry Processing Trial.

\section{References}

Bergers, W.W. 1980. A rapid quantitative assay for solanidine glycoalkaloids in potatoes and industrial potato protein. Potato Research 23: 105-110.

Bradford, N.M. 1976. A rapid and sensitive method for the quantitation of microgram quantities of protein using the principle of protein dye binding. Analytical Biochemistry 72: 248-254.

Bradshaw, J. 2007. Potato-breeding strategy. In Potato biology and biotechnology, advances and perspectives, ed. D. Vreugdenhil, 157177. Oxford: Elsevier Ltd..

Brown, C.R., H. Mojtahedi, G.S. Santo, P. Hamm, J.J. Pavek, D. Corsini, S. Love, J.M. Crosslin, and P.E. Thomas. 2000. Potato germplasm 
resistant to corky ringspot disease. American Journal of Potato Research 77: 23-27.

Brown, C.R., H. Mojtahedi, J.M. Crosslin, S. James, B. Charlton, R.G. Novy, S.L. Love, M.I. Vales, and P. Hamm. 2009. Characterization of resistance to Corky ringspot disease in potato: a case for resistance to infection by tobacco rattle virus. American Journal of Potato Research 86: 49-55.

Corsini, D., and J.J. Pavek. 1986. Fusarium dry-rot resistant potato germplasm. American Potato Journal 63: 629-638.

Corsini, D.L., J.J. Pavek, and J.R. Davis. 1988. Verticillium wilt resistance in non-cultivated tuber-bearing Solanum species. Plant Disease 75: 148-151.

Corsini, D.L., J.J. Pavek, M.W. Martin, and C.R. Brown. 1994. Potato germplasm with combined resistance to leafroll virus and viruses $\mathrm{X}$ and Y. American Potato Journal 71: 377-385.

European Cultivated Potato Database, The. http://www.europotato. org/menu.php, Accessed October 25, 2016).

Haynes, K.G., B.J. Christ, D.P. Weingartner, D.S. Douches, C.A. Thill, G. Secor, W.E. Fry, and D.H. Lambert. 2002. Foliar resistance to late blight in potato clones evaluated in national trials in 1997. American Journal of Potato Research 79: 451-457.

Herman, D.J., L.O. Knowles and N.R. Knowles. 2016. Screening sweetening-resistant clones for tolerance to heat stress. Proceedings of the 99th Annual Meeting of the Potato Association of America. American Journal of Potato Research 93:132.

Johansen, R.H., B. Farnsworth, D.C. Nelson, G.A. Secor, N. Gudmestad, and P.H. Orr. 1988. Russet Norkotah: a new russet-skinned potato cultivar with wide adaptation. American Potato Journal 65: 597 604

Knowles, N.R., D. Herman, C. Dean, G. Ellis, L. Knowles and M. Pavek. 2016. Use of growth regulators to optimize plant growth, tuber set and shape of new varieties. Proceedings of the annual Washington and Oregon potato conference, Jan. 27-28, Kennewick, WA. pp. $55-62$.

Kumar, G.N.M., L.O. Knowles, and N.R. Knowles. 2015. Zebra chip disease decreases tuber (Solanum tuberosum L.) protein content by attenuating protease inhibitor levels and increasing protease activities. Planta 242: 1153-1166.

Lang, N.S., R.G. Stevens, R.E. Thornton, W.L. Pan, and S. Victory. 1999. Nutrient Management Guide: Central Washington Irrigated Potatoes. Washington State University Experiment Station Extension Bulletin EB1882.

Love, S.L., R. Novy, D.L. Corsini, J.J. Pavek, A.R. Mosley, R.E. Thornton, S.R. James, and D.C. Hane. 2002. Gem russet: a long russet potato variety with excellent fresh market and french fry processing quality. American Journal of Potato Research 79: 25-31.

Love, S.L., R.G. Novy, J.L., Whitworth, D.L. Corsini, J.J. Pavek, A.R. Mosley, M.J. Pavek, N.R. Knowles, C.R. Brown, S.R. James, D.C. Hane, and J.C. Miller. 2006. GemStar russet: a potato variety with high yield, good culinary quality, excellent fresh market appearance, and resistance to common scab. American Journal of Potato Research 83:171-180.

Milbourne, D., R.C. Meyer, A.J. Collins, L.D. Ramsay, C. Gebhardt, and R. Waugh. 1998. Isolation, characterization and mapping of simple sequence repeat loci in potato. Molecular and General Genetics 259: 233-245.

Mosley A. S., Yilma, D. Hane, S. James, K. Rykbost, C. Shock, B. Charlton, E. Eldredge, and L. Leroux. 2003. Oregon. In: K.G. Haynes (ed), National Potato Germplasm Evaluation and Enhancement Report, 2001. pp. 369-388.

Novy, R.G., S.L. Love, D.L. Corsini, J.J. Pavek, J.L. Whitworth, A.R. Mosley, S.R. James, D.C. Hane, C.C. Shock, K.A. Rykbost, C.R. Brown, R.E. Thornton, N.R. Knowles, M.J. Pavek, N. Olsen, and D.A. Inglis. 2006. Defender: a high-yielding, processing potato cultivar with foliar and tuber resistance to late blight. American Journal of Potato Research 83: 9-19.

Novy, R.G., J.L. Whitworth, J.C. Stark, B.A. Charlton, S. Yilma, N.R. Knowles, M.J. Pavek, T.L. Brandt, S. Gupta, N. Olsen, M. Thornton, C.R. Brown, D.L. Corsini, J.J. Pavek, S.R. James, D.C. Hane, H. Lozoya-Saldana, and M.I. Vales. 2012. Palisade russet: a late blight resistant potato cultivar having a low incidence of sugar ends and high specific gravity. American Journal of Potato Research 89: 89-101.

Pavek M.J. and N.R. Knowles. 2014. WSU potato cultivar yield and postharvest quality evaluations for 2013. Washington State University Special Report. 122 pages.

Pavek, M.J. and Knowles, N.R. 2016. WSU potato cultivar yield and postharvest quality evaluations for 2015. Washington State University Special Report. January, 2016, 112 pages.

Pavek, J.J., D.L. Corsini, J.G. Garner, S. Michener, W.C. Sparks, G.F. Carnahan, C.E. Stanger, A.R. Mosley, M.J. Johnson, G.E. Carter, R.E. Voss, M.W. Martin, and R.H. Johansen. 1981. Lemhi russet: a new high yielding potato variety with wide adaptation, attractive tubers, and high internal quality. American Potato Journal 58: 619-625.

Ross, F.A. 1959. Dinitrophenol method for reducing sugars. In Potato Processing, ed. W.F. Talburt and O. Smith, 469-470. Westport: AVI Publ.

Schisler, D.A., P.J. Slininger, G.E. Kleinkopf, R.J. Bothast, and R.C. Ostrowski. 2000. Biological control of Fusarium dry rot of potato tubers under commercial storage conditions. American Journal of Potato Research 77: 29-40.

Solomon-Blackburn, R.M., and H. Barker. 2001. Breeding virus resistant potatoes (Solanum tuberosum): a review of traditional and molecular approaches. Heredity 86: 17-35.

Song, Y.S., and A. Schwarzfischer. 2008. Development of STS markers for selection of extreme resistance $\left(R y_{\text {sto }}\right)$ to PVY and maternal pedigree analysis of extremely resistant cultivars. American Journal of Potato Research 85: 159-170.

United States Standards for Grades of Potatoes. 2011. United States Department of Agriculture, Agricultural Marketing Service. p 2

Valkonen, J.P.T., K. Wiegmann, J.H. Hamalainen, W. Marczewski, and K.N. Watanabe. 2008. Evidence for utility of the same PCR-based markers for selection of extreme resistance to Potato virus $Y$ controlled by $R y_{\text {sto }}$ of Solanum stoloniferum derived from different sources. The Annals of Applied Biology 152: 121-130.

Wang, Yi, P.C. Bethke, A.J. Bussan, M.T. Glynn, D.G. Holm, F.M. Navarro, R.G. Novy, J.P. Palta, M.J. Pavek, G.A. Porter, V.R. Sathuvalli, A.L. Thompson, P.J. Voglewede, J.L. Whitworth, D.I. Parish, and J.B. Endelman. 2016. Acrylamide-forming potential and agronomic properties of elite U.S. potato germplasm from the National Fry Processing Trial. Crop Science 56: $1-10$.

Webb, R.E., D.R. Wilson, J.R. Shumaker, B. Graves, M.R. Henninger, J. Watts, J.A. Frank, and H.J. Murphy. 1978. Atlantic: a new potato variety with high solids, good processing quality, and resistance to pests. American Potato Journal 55: 141-145.

Zommick, D.H., L.O. Knowles, M.J. Pavek, and N.R. Knowles. 2014a. In-season heat stress compromises postharvest quality and low temperature sweetening resistance in potato (Solanum tuberosum L.). Planta 239: 1243-1263.

Zommick, D.H., L.O. Knowles, and N.R. Knowles. 2014b. Tuber respiratory profiles during low temperature sweetening (LTS) and reconditioning of LTS-resistant and susceptible potato (Solanum tuberosum L.) cultivars. Postharvest Biology and Technology 92: $128-138$. 